\title{
THOMAS MANN Y EL RETORNO DE LO REPRIMIDO: VIDA U OBRA
}

\author{
KEVIN MATOS \\ Universidad de Puerto Rico \\ kevin.matos@upr.edu \\ ORCID: 0000-0001-6690-8108
}

\section{RESUMEN}

Este ensayo explora el constante motivo fundamental que da cohesión a toda la obra de Thomas Mann: el «desplome de una actitud trabajosamente obtenida y cultivada a través de la inteligencia y la renuncia» y el «ululante triunfo del mundo de los instintos». Dicho de otro modo: el retorno de lo reprimido. Detrás de la extraordinaria congruencia y organicidad del universo poético manniano laten angustias eróticas que acuciaron al hombre de carne y hueso. Estas páginas exploran la transfiguración poética de tales pulsiones, en esencia homoeróticas, en obras como $E l$ pequeño señor Friedemann, El payaso, Tonio Kröger, Muerte en Venecia y La montaña mágica, entre otras, donde su autor alcanza admirables cúspides de silencio velado.

PALABRAS CLAVE: literatura alemana, erotismo, homoerotismo, amor, soledad, Thomas Mann.

\section{THOMAS MANN AND THE RETURN OF THE REPRESSED}

\section{ABSTRACT}

This essay explores the basic motif which to some extent holds together Thomas Mann's literary work: «the collapse of a highly cultivated poised attitude, laboriously won by judgement and renunciation» and the «triumph of the suppressed world of instinct». In other words: the return of the repressed. Behind the extraordinary congruence and organicity of Mann's poetic universe lie erotic anguishes that beset the author. These pages explore the poetic transfiguration of such drives, essentially homoerotic, in works such as Der kleine Herr Friedemann, Der Bajazzo, Tonio Kröger, Der Tod in Venedig and Der Zauberberg, among others, where the author reaches admirable peaks of veiled silence.

KEYWORDS: German literature, eroticism, homoeroticism, love, solitude, Thomas Mann.

\author{
A Hermann Kurzke, \\ a Esteban Tollinchi y a Víctor Castro. \\ Ich leb' allein in meinem Himmel, \\ in meinem Lieben, in meinem Lied! \\ Friedrich Rückert
}

Toda vida es retorno y repetición. Thomas Mann, On Myself 
« ¡Silencio en todos los sótanos!; que todos los perros estén bien encadenados». ${ }^{1}$ Con esta contundencia, proclama Thomas Mann su renuncia a las pulsiones homoeróticas. En una carta a su amigo y confidente Otto Grautoff, a quien se había atrevido a confesarle la lacerante angustia sexual que lo acuciaba, expresa: «Cómo la odio, esta maldita sexualidad» (8 de noviembre de 1896, apud Kurzke 2004: 80). En otra carta previa de ese mismo año (17 de febrero de 1896), exhortaba a su amigo, como si se hablara a sí mismo, a que renunciara a ella, intentaba hacerlo entrar en razón y le aconsejaba que dejara morir sus impulsos, absolutamente incompatibles con su esencia de homme des lettres:

Hay que debilitar y marchitar lenta y cuidadosamente el impulso. [...] Tienes tiempo, y tu instinto de calma y de autosafistacción ya logrará encadenar a los perros que tienes en el sótano. (apud Kurzke 2004: 81)

Sus recetas, que incluían baños de agua fría por las mañanas, no le bastaban. «¿Cómo puedo liberarme de la sexualidad?», vuelve a escribirle atormentado a Grautoff desde Italia. Esta sempiterna angustia lo acompañaría de por vida, pero él fue capaz de transfigurarla, de sublimarla y de convertirla en arte hasta alcanzar admirables cúspides de silencio velado. Toda su obra, su inmensa creación literaria, parece girar en torno a ella, en torno a lo que Hermann Kurzke llama «Ur-Kram» y que Rosa Sala bien traduce como «papilla primigenia» (1999: 86, 2004: 86):

Los millones de palabras que Thomas Mann ha generado en el transcurso de su vida no hacen sino envolver un silencio primigenio. Toda esa elocuencia es una cáscara exterior que envuelve algo indecible y sagrado, cuya naturaleza, en el fondo, es erótica. (Kurzke 2004: 50)

Más adelante el biógrafo explica:

Él «es» Friedemann, un asceta que lee y toca el violín, que ha sabido encadenar exitosamente sus perros en el sótano. El motivo fundamental de su vida y de su obra es el miedo a la pasión, el miedo a que pudiera descompensarse su celosamente vigilado equilibrio vital, el miedo al retorno de lo reprimido y al socavamiento del fiel artificio. [...] Sus grandes obras siempre cuentan la historia del retorno de lo reprimido. (Kurzke 2004: 89-90)

Pero cumple aclarar que no se trata de una invención ni de una lúcida intuición del biógrafo. Es el propio Thomas Mann quien lo reconoce en su conferencia titulada On Myself. ${ }^{2}$ Haciendo un recuento de su vasta producción literaria y

\footnotetext{
${ }^{1}$ Son palabras de Nietzsche, La genealogía de la moral (III, 8): «Ruhe in allen Souterrains; alle Hunde hübsch an die Kette gelegt» (Nietzsche Source).

${ }^{2}$ Conferencia en dos partes pronunciada en el seminario «Literatura alemana de los siglos XIX y XX» del profesor Hans Jaeger en la Universidad de Princeton los días 2 y 3 de mayo de 1940. Para no abrumar al lector con demasiadas indicaciones bibliográficas a lo largo del texto, siempre que cite a Thomas Mann indicaré entre paréntesis únicamente el número de página cuando se trate de citas literarias, precedido en ocasiones del libro o capítulo para las novelas largas,
} 
explicando los avatares que la hicieron posible, declara el relato El pequeño señor Friedemann como un verdadero hito, puesto que introduce el «constante motivo fundamental que, en cierto modo, da cohesión a toda [su] obra», la llamada «papilla primigenia» $\mathrm{O}$ «Ur-Kram»:

Esta melancólica historia del pequeño jorobado representa también un hito en mi historia personal, en la medida en que toca por vez primera un motivo fundamental que representa en toda mi obra el mismo papel que el leitmotiv en la obra individual. El personaje principal es una persona maltratada por la Naturaleza, que sabe conformarse con su destino de manera mansa e inteligente, pacífica y filosófica, y ha ajustado su vida entera a la tranquilidad, la contemplación y la paz. La aparición de una mujer extrañamente hermosa, a la vez que fría y cruel, significa una irrupción de la pasión en esa vida protegida que destruye toda su arquitectura y aniquila al tranquilo héroe. (Mann 2016a: 63)

\section{Mann ilustra el motivo con una cita de José en Egipto:}

... nada más empezar nuestra actividad espiritual, cuando entramos en la vida de la cultura, como lo hizo antaño la Humanidad, dando forma y haciendo nuestra primera y delicada aportación, topamos con una comprensión y predilección que nos permite, con alegre asombro, sentir y reconocer aquella unidad, que es siempre la misma: es la idea del asedio, la irrupción de poderes embriagadoramente destructores y aniquiladores en una vida contenida y entregada con todas sus esperanzas a la dignidad y a la condicionada dicha de la contención. La canción de la paz alcanzada, en apariencia asegurada, y la de la vida que barre entre risas esa fiel construcción artificial; del dominio y la superación, de la llegada del Dios desconocido, estuvo en el principio, como estaba en el centro. $\mathrm{Y}$ en una etapa tardía de la vida que se entrega con simpatía a las primicias humanas nos vemos nuevamente forzados a esa vieja comprensión, bajo el signo de la unidad. (Mann 2016a: 6364; énfasis mío) ${ }^{3}$

«El arco se tiende desde El pequeño señor Friedemann hasta Muerte en Venecia», señala el autor (64). El arco se extiende muchísimo más - y tendremos ocasión de constatarlo-, pero importa insistir que es el propio Thomas Mann quien declara el núcleo en torno al cual gira toda su obra, ese «desplome de una actitud trabajosamente obtenida y cultivada a través de la inteligencia y la renuncia» y el «ululante triunfo del mundo reprimido de los instintos». No sorprende, pues, que el propio autor confiese de modo inequívoco el carácter autobiográfico que asume toda su obra a partir de El pequeño señor Friedemann (1897):

Desde El pequeño señor Friedemann sé reconocer de repente las discretas formas y máscaras por medio de las que puedo hacer públicas mis propias experiencias. Mientras que antes,

mientras que para las citas provenientes de diarios, ensayos o conferencias indicaré el año de la edición manejada en la que se contiene dicho texto. Siempre cito a partir de las ediciones consignadas en la bibliografía y quedará claro en el cuerpo del texto a qué obra pertenece la cita. Todas las citas de relatos cortos y Novellen provienen de la colección de Cuentos completos. Citas consecutivas de una misma fuente serán identificadas solo con el número de página entre paréntesis, mientras que citas consecutivas de una misma página solo se identificarán una vez.

${ }^{3}$ Cito a partir de On Myself. El pasaje corresponde a «La serpiente de la agonía» de la sexta parte de José en Egipto, tercera novela de la tetralogía José y sus hermanos. 
aunque solo quisiera comunicarme a mí mismo, me hacía falta un diario secreto... (apud Kurzke 2004: 85)

En otra carta a Grautoff, vuelve a insistir en ello:

Desde hace algún tiempo me siento como si se me hubieran soltado los codos, como si hubiera encontrado medios y caminos para desahogarme, expresarme, desfogarme artísticamente, y mientras antes requería de un diario a fin de aliviarme, aunque solo fuera para mis cuatro paredes, ahora encuentro formas y máscaras novelísticas susceptibles de ser expuestas al público [...] Creo que todo esto empezó con El pequeño señor Friedemann. (apud Kurzke 2004: 86)

Las páginas que siguen recorren la senda trazada sensible y magistralmente por Hermann Kurzke y señalada por el propio Thomas Mann. Habremos de detenernos en las obras mismas, esto es, en la transfiguración artística de estas convulsas pulsiones eróticas. «Desplazamiento del deseo, nostalgia de lo deseado, alejamiento y resurgimiento de lo reprimido», por ponerlo en palabras de Blas Matamoro (1981: 262), serán «constantes (diríamos hoy freudianas) en toda la invención y la reflexión de nuestro escritor». La inmensidad de la obra manniana nos obliga a limitar nuestras reflexiones a algunos personajes, representativos, eso sí, de la gran complejidad de caracteres hermanados por una misma sensibilidad: el señor Friedemann, el Bajazzo, Tonio Kröger y Gustav von Aschenbach, sin pasar por alto algunas vivencias de Hans Castorp, Adrian Leverkühn y Félix Krull. La renuncia a Eros, a estas pulsiones vitales intrínsecas al hombre, nunca será absoluta, no importa el ahínco ni las veces que sea procamada. Siempre habrá de tornar, a pesar de todo, la «maldita sexualidad». «Toda vida es retorno y repetición», nos dice Thomas Mann en On myself (2016a: 93). Los perros del sótano siempre tienen sed de libertad.

\section{EL PEQUEÑO SEÑOR FRIEDEMANN O EL ESPÍRITU DE RENUNCIA}

Con la exclamación que inician estas páginas, Nietzsche resume la actitud milenaria que ha asumido Occidente ante el convulso mundo de las pasiones humanas: amansarlas, sosegarlas, acallarlas mediante la preponderancia de la voz de la razón, reprimirlas o extirparlas a fin de librarse de la condenación eterna, es decir, de la tristeza mortal en esta vida o del posible castigo sempiterno en la otra. El asceta ha de renunciar con todas sus fuerzas al estallido de grandes pasiones, ha de refrenarlas y nunca, jamás dejarse arrastrar por el torbellino que estas suponen. Anhela una vida dulce y apacible, sin grandes afectos, pero en paz serena.

\footnotetext{
${ }^{4}$ Vale decir que este era el procedimiento literario habitual de toda la familia Mann: encontrar y revelar antes que inventar. Los hijos de Thomas Mann se referían a los «crímenes narrativos del Mago» (Lahme 2019: 48) y a menudo despertaba malestares en quienes se veían retratados sobre el papel. Varias veces Thomas Mann declara públicamente ser un autor autobiográfico; véanse, por ejemplo, Bilse y yo (1975: 13-26) y Lübeck como forma de vida espiritual (2016a: 48).
} 
El fino oído de Nietzsche, sin embargo, con su innata perspicacia y hondura psicológica, oye ladrar los perros y reconoce que, pese a la aparente quietud que exhibe el domador de fieras, una batalla muy violenta se libra en su interior, donde bulle todo un caudal de pulsiones y de fuerza que reclama libertad:

También tus malos instintos tienen sed de libertad. Tus perros salvajes quieren libertad; ladran de placer en su cueva cuando tu espíritu se propone abrir todas las prisiones. (Así habló Zaratustra, «Del árbol de la montaña», p. 93).

Por mucho que intente defender su paz, siempre ha de retornar la rebelión interior de todo lo reprimido, de todo lo renunciado con el solo fin de evadir todo tormento y perdición. Frente a la cautela extrema de quien renuncia a grandes placeres a fin de evitar grandes dolores, Nietzsche se pregunta:

¿Y qué si el placer y el displacer estuvieran atados con una cuerda de manera tal que quien quiere tener lo más posible de uno tiene que tener lo más posible del otro, —que quien quiere aprender el «júbilo celeste» tiene que estar preparado también para la tristeza mortal? ( $L a$ gaya ciencia 12, p. 747 )

El hombre lúgubre, que tanto denuncia el «carácter terrible de las pasiones humanas», ha convertido a las pasiones en «monstruos», sin darse cuenta de que, al hacerlo, estas podrían retornar con tal ímpetu que se conviertan en «fatalidades eternas». El filósofo invita a «quitar a las pasiones su carácter terrible y precaverlas de tal modo que no se conviertan en torrentes devastadores» (Humano, demasiado humano, «El caminante y su sombra», 37, p. 389), a asumirlas, a despojarlas de su carácter negativo, a reconocerlas como un componente esencial de la vida y a transfigurarlas para darles cierto orden y dirección: «En otro tiempo tenías perros salvajes en tu mazmorra: pero al final se transformaron en pájaros y en amables cantoras» (Así habló Zaratustra, «De las alegrías y las pasiones», p. 82).

Esta batalla a muerte se libra en el interior del señor Friedemann, hombre maltratado por la naturaleza con una deformidad física que le veda para siempre la posibilidad de toda experiencia erótica. «El pequeño Johannes no era nada hermoso», dice el narrador,

y verlo así, sentado sobre el banquillo con el pecho puntiagudo y elevado, la espalda profundamente encorvada, y los brazos demasiado largos y flacos cascando nueces con ágil afán, constituía una visión singular en extremo. (90-91)

A los dieciséis se enamoró de una muchacha rubia y desenvuelta, pero sufrió un profundo desengaño al descubrirla besando a un joven alto, de seguro muy guapo, desengaño que lo llevó a renunciar para siempre al amor:

«Muy bien — se dijo a sí mismo—, se ha terminado. No quiero volver a preocuparme nunca más por este tipo de cosas. Puede que a los demás les procure felicidad y alegría, pero a mí no va a traerme sino aflicción y dolor. Se acabó. No voy a darle más vueltas. Nunca más».

La decisión le sentó bien. Había renunciado, renunciado para siempre. Se fue a casa y 
cogió un libro o tocó el violín, actividad que había aprendido a pesar de la deformación de su pecho. (92)

Se refugió, pues, en la música y en la literatura. Ajustó su vida entera a la contemplación sosegada de la belleza. Amaba la música y acudía a cuanto concierto había. Desarrolló un buen gusto literario y se deleitaba en él, aunque no pudiera compartirlo con nadie. Era feliz. Vivía apartado del mundo, perdido para el mundo. Había creado para sí un paraíso entrañable que amaba, «amaba con ternura esa vida que transcurría de un modo dulce, sin grandes afectos, pero llena de una felicidad serena y delicada que él sabía procurarse a sí mismo» (94):

Ich bin gestorben dem Weltgetümmel,

und ruh' in einem stillen Gebiet!

ich leb' allein in meinem Himmel,

in meinem Lieben, in meinem Lied!

Este Lied compuesto por Gustav Mahler a partir de un poema de Friedrich Rückert — «Ich bin der Welt abhanden gekommen»— parece resumir la actitud vital tanto del señor Friedemann como de múltiples personajes mannianos y nos provee, sin duda, una clave importante para acercarnos a su desgarramiento existencial. Deviene íntimamente su himno vital. (Llegaremos a escucharlo de labios de Hans Castorp).

¿Acaso la vida no es un bien por sí mismo, aunque no se desarrolle precisamente de un modo que podamos considerar «feliz»? Johannes Friedemann lo sentía así y amaba la vida. Nadie es capaz de comprender con qué íntimo detalle precisamente él, que había renunciado a la máxima felicidad que la vida puede brindarnos, sabía disfrutar de los placeres que esta ponía a su alcance. (93)

La música era su forma más intensa de voluptuosidad, la vía para satisfacer ese deseo erótico latente. Lo mismo sucederá al payaso (El payaso, 1897), a Hanno Buddenbrook (Los Buddenbrook, 1901), a Gabriele Klöterjahn (Tristán, 1903), a los protagonistas de Sangre de Welsungos (1905), a Hans Castorp (La montaña mágica, 1924) y a Adrian Leverkühn (Doktor Faustus, 1947).

«Así fue pasando el tiempo, pacífico y ordenado». Llegó a los treinta, aunque no había cambiado mucho — seguía imberbe-, hasta que una noche en que se representaba Lohengrin — «der Gipfel der Romantik», en palabras de Thomas Mann ${ }^{6}$ - acudió al teatro, como de costumbre. Con paso seguro, entró a su palco, «con impecable traje negro y reluciente pechera blanca» (100) — «curiosamente, era un poco vanidoso», comenta el narrador (94)- y de improviso sufrió un profundo sobresalto: al lado izquierdo de su butaca estaba

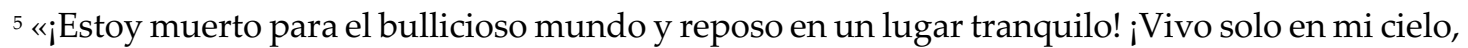
en mi amor, en mi canción!».

6 «La cumbre del Romanticismo». Así se refiere al preludio en una radiodifusión en el Süddeutscher Rundfunk en julio de 1954. También en Wagner y nuestro tiempo de 1931 (Mann 2013: 72) y en carta a Emil Preetorius de 1949 (Mann 2013: 188).
} 
sentada la señora von Rinnlingen, a quien el solitario, fascinado por su deslumbrante belleza, había perseguido con la vista días antes en sus paseos habituales.

Cuando sonaron los primeros acordes de la obertura y la señora von Rinnlingen se inclinó sobre el antepecho, el señor Friedemann deslizó brusca y fugazmente la mirada hacia ella. Llevaba un vestido de gala claro y era la única de las damas presentes que incluso iba algo escotada. (100)

Las vaporosas mangas revelaban la blancura de su piel. «Su figura se revelaba exuberante [...] Su pecho subía y bajaba lentamente en toda su plenitud». Los ojos del señor Friedemann permanecían clavados sobre su esbelta figura mientras la música sonaba.

La señora von Rinnlingen se había quitado el guante del brazo izquierdo que tenía apoyado sobre el terciopelo rojo del antepecho y él no tuvo más remedio que ver durante todo el rato ese brazo redondo y de mate blancura, cubierto, al igual que la mano desnuda, de finas venas de color azul pálido. Era inevitable. (100-101)

El pequeño señor Friedemann palideció, tenía la frente perlada de sudor bajo su liso cabello rubio oscuro. De pronto, cayó al suelo el abanico de la señora. Ambos se agacharon al mismo tiempo, casi se rozaron, estaban tan cerca el uno del otro que él «se había visto obligado a respirar el cálido aroma de su pecho» (101). «Ich danke», dijo ella sonriente. Él

tenía el rostro desencajado, se le había contraído todo el cuerpo y su corazón palpitaba de un modo tan terriblemente pesado e impetuoso que se quedó sin aliento. Permaneció sentado medio minuto más y entonces empujó la butaca hacia atrás, se puso en pie sin hacer ruido y se fue en silencio. (100-101)

Toda la escena respira erotismo. A menudo, Eros aguarda a las almas solitarias en los teatros: no importa cuán apartado del mundo esté nuestro protagonista, cuánto disfrute de su soledad y de su mundo interior, el teatro implica necesariamente el encuentro con el otro, la congregación de almas hermanadas por un mismo placer - en este caso la música - en un mismo espacio cerrado. En el estrecho palco compartido con la señora von Rinnlingen, la tensión erótica es inevitable: se excitan sin remedio los perros del sótano. Allí encuentra inesperadamente aquello a lo que había renunciado con todas sus fuerzas, pero que en el fondo siempre había deseado y le había sido vedado. El aura de elegancia y belleza física que inunda el lugar propicia de igual manera el resurgir de la nostalgia, del anhelo de compañía y aun del ansia de satisfacer carnalmente la pasión que suscita la música. ¡Y más aún la música de Wagner, 
que para Thomas Mann siempre supone seducción, ebriedad, disolución y, en última instancia, muerte! ${ }^{7}$ Es lo que le ocurre al pequeño señor Friedemann.

Todo su ser se conmocionó para siempre:

Estaba escudriñando con mirada horrorizada y temerosa su interior y viendo cómo su sensibilidad, que con tanto esmero había cuidado siempre, a la que trataba con tanta dulzura e inteligencia, se había visto violentamente sacudida, agitada, desquiciada... Y de repente, totalmente trastornado, en un estado de aturdimiento, ebriedad, nostalgia y tormento, se apoyó contra una farola y susurró trémulo: «iGerda!». (102)

Su vida ya no sería la misma. Su cielo perdió esplendor, la música cesó: «¿Qué le importaban todas esas cosas que habían constituido hasta entonces su felicidad? [...] ¡Qué cansado y débil se sentía!» (103). Su felicidad se disolvió en una «melancolía grande». Tenía miedo. Sentía haber perdido todo control de sí. «Una especie de temeridad empezaba a invadirle» (105). Determinó ir a verla y no había vuelta atrás. Decidió dar rienda suelta a su pasión. «Su fatigada cabeza le palpitaba implacablemente» (109), «icon qué atormentadora agitación bullía todo en su interior» (110). «PPaz, paz era lo único que deseaba!», pero ya era tarde. Rememoró su felicidad perdida y la añoró, «pero entonces había venido aquella mujer», «había tenido que rebelarse en su interior todo lo que había estado reprimiendo desde su juventud porque sabía que para él solo iba a significar tormento y perdición. ¡Se había apoderado de su ser con una violencia espantosa e irresistible y lo estaba aniquilando! Lo estaba aniquilando, de eso se daba buena cuenta» (111). Pero tenía que obedecer su destino, ese «poder sobrehumano y de mortificante dulzura al que nadie es capaz de escapar».

Recibió una invitación de la señora a una pequeña reunión social que celebraría en su casa. Él acudió cuidadosamente vestido, como de costumbre, con su frac impecable y su camisa almidonada, zapatos de charol y con el leve toque extravagante que le conferían los calcetines de seda roja que llevaba. Su palidez, con todo, era alarmante. Tenía las mejillas hundidas, los ojos enrojecidos rodeados de sombras oscuras, que le daban a su figura un aspecto «indeciblemente triste» (112). Se habían exteriorizado los síntomas de su pasión, se intuía la muerte, aunque nadie se fijara en él. Había en su mirada «algo de embotamiento y de muerte, una entrega sorda, exánime y ajena a toda voluntad» (114). Salió al jardín con ella y ambos tomaron asiento en un banco frente al agua. Charlando, le confesó que nunca ha sido feliz, aunque lo había intentado: «Todo fue engaño y mentira» (116). Soltó los perros. Hubo un roce delicado, la tomó de la mano, se arrodilló contrahecho, tutto tremante apretó su rostro contra su regazo, pero apenas pudo decir palabra. Ella, «con una carcajada breve, altiva y llena de desdén», lo empujó, se levantó de un salto y desapareció. «Él quedó allí tendido, el rostro contra la hierba, aturdido, fuera de sí, mientras un estremecimiento

\footnotetext{
${ }^{7}$ En su vejez, Thomas Mann ve el segundo acto del Tristán como propio de los jóvenes que no logran encontrar salida alguna para su sexualidad o que andan desconcertados con ella (carta a Preetorius en 1949, 2013: 187).
} 
convulsivo sacudía su cuerpo a cada instante» (116-117). ¿Por qué lo hizo? ¿Qué lo llevó a emprender tal locura? «Tal vez fuera una repugnancia por su propia persona la que lo invadió con el ansia de destruirse, de desgarrarse en pedazos, de extinguirse...» (117). La muerte lo seducía. Lo seducía el abismo. Se dejó caer en el agua, se abandonó a ella y no volvió a levantar la cabeza. La naturaleza, al igual que los invitados, siguió su curso, infinitamente indiferente. «Tenía que ser así, era su destino» $(110-111)$.

El pequeño señor Friedemann, pese a su espíritu de renuncia, sería acaso el único que se arriesgara a dar libre curso a su furor, a superar sus inhibiciones, aunque hubiese de sucumbir en el intento. El amor de Mann, tanto el real como el literario, es siempre silencioso. Solo el «infeliz jorobado»-como solo su autor ante Armin Martens _ daría este paso que supuso una humillación tan profunda que desembocó en el silencio y en la renuncia. Hans Castorp intentará superararla — pronto lo veremos_, amparado en la lengua francesa, que equivale a hablar en sueños, pero no ganará mucho. Mientras tanto, este contenido insoportable, este erotismo angustiado, permanecerá oculto en lo más recóndito del inconsciente, siempre listo para retornar.

\section{«AH, HE SABIDO ORGANIZARME LA VIDA A MI GUSTO! ¿ACASO NO SOY FELIZ?»}

Existe un alma afín a la del pequeño señor Friedemann, tan afín que casi podrían confundirse sus identidades sin problema. Ignoramos su nombre, pero podríamos referirnos a él simplemente como «el payaso». Este relato, titulado en efecto El payaso, se publicó el mismo año que el anterior: 1897. Al igual que el señor Friedemann, el protagonista renuncia para siempre a esa «felicidad exterior» que gozan las «personas luminosas que se pasean por la vida de una forma ligera, agradable y benévola y con el reflejo del sol en sus ojos mientras todo el mundo las rodea y las admira, elogia, envidia y quiere» (138). Renuncia a la vida común o trivial, y organiza su vida, «sin gente», a su gusto. La soledad le procura grandes alegrías, grandes gozos y numerosos instantes de plenitud. De niño, se perdía en el ensueño melancólico de los Nocturnos de Chopin que su madre tocaba al piano. De adulto, se entrega a la fantasía musical, a improvisar en el piano sonoridades infinitas, sin ritmo definido ni melodía, puras transposiciones armónicas. Cuando no, siempre tiene a mano un libro que le permite sentir junto con cada personaje, experimentar sus movimientos anímicos o pasiones, identificarse y perderse en nuevas identidades. Desde niño había sido aficionado a las máscaras, se pasaba horas entregado a «agotadoras representaciones» dramáticas y musicales con su teatrillo se marionetas. Los efectos que en él produce el arte son casi orgiásticos. Las obras de arte lo «sacuden, anestesian, atormentan, embriagan y aniquilan» (137), agitan su fantasía, estremecen sus nervios, lo electrizan... Vaticina al futuro Hanno 
Buddenbrook, que en sus fantasías al piano se abandonará a la seducción de la música, a ese abismo de perdición, ${ }^{8}$ como sucederá en la celebración de su octavo cumpleaños, cuando presente al público familiar, a dúo con su madre, «una pequeña fantasía que él mismo había inventado» (Los Buddenbrook, VIII, 6: 600). Recordemos, de una parte, que fantasear al piano supone un ejercicio estético que no lleva a ninguna parte, pues no conforma ninguna obra coherente $o$ rígidamente estructurada, sino que consiste en regodearse en la seducción de la música. Supone un abandono a la fantasía desbordante y a lo amorfo, a la infinitud. La música del pequeño Buddenbrook «poseía un carácter más armónico que rítmico» (601), se basaba en contrastes y en vertiginosos giros armónicos. El carácter de esta fantasía, de otra parte, evoca las melodías infinitas y acordes interminables de la ópera wagneriana Tristan und Isolde:

Y ahora venía el final, aquel final que tanto amaba Hanno. [...] Iba en aumento, crecía, parecía que se hinchaba lenta, muy lentamente [...] No quería llegar a la resolución, la retrasaba tanto para sí mismo como para el público. ¿Qué supondría aquella resolución, aquella gozosa liberación de resolver en si mayor? ¡Una dicha sin fin, una satisfacción de una dulzura desbordante! [...] Aún no..., ¡aún no! Un instante más de dilación, de espera, de tensión, pues ha de hacerse del todo insoportable para que la liberación resulte tanto más deliciosa... Un último, un ultimísimo momento de ese imperioso y angustioso anhelo, de esa ansia de todo el cuerpo, de ese deseo refrenado hasta la crispación más extrema; deseo que, a pesar de todo, aún se niega a cumplirse y a traer la liberación, porque sabe algo fundamental: la felicidad solo dura un instante... (601-602)

Es imposible pasar por alto el encendido erotismo de la escena. Previo a ese instante de felicidad, sobreviene una crispación extrema del cuerpo, una tensión insoportable de placentera, cuya resolución, ese brevísimo instante de deliciosa dulzura, culmina en un letargo comparable a la muerte:

El cuerpo de Hanno se elevó lentamente, sus ojos se tornaron gigantescos, sus labios apretados comenzaron a temblar, como también las tiernas aletas de su nariz al tomar aire entrecortadamente..., y luego ya no hubo forma de contener el estallido de placer. Llegó, se apoderó de él y él ya no opuso resistencia alguna. Sus músculos se relajaron y, exhausto,

\footnotetext{
${ }^{8}$ El narrador de Los Buddenbrook, haciéndose eco de los pensamientos de Thomas Buddenbrook por medio del estilo indirecto libre, establece una relación directa entre música y decadencia: « $\mathrm{Si}$ al menos hubiera podido reprimir y eliminar de su vida la música, aquella fuerza que alejaba al niño de la vida práctica y lo enajenaba, que sin duda no beneficiaba en absoluto su salud física y que absorbía todas sus energías intelectuales!»(VIII, 7: 618-619). Incluso abandonarse a la seducción de la música, a su erotismo, puede conducir directamente a la muerte. El ejemplo supremo de ello es Tristán (1903), sin olvidar que la música de Lohengrin, al igual que la de Gounod para el payaso, es lo que compele al pequeño señor Friedemann a declararse, es decir, lo que lo conduce a su perdición.

Aunque no nos ocupamos aquí de Thomas Buddenbrook, cumple decir que este personaje constituye una de las principales encarnaciones del espíritu de renuncia. Las máscaras, su constante representación de un papel, su obsesiva atención al aseo, todo esto encubre sus renuncias, siendo la primera de todas la erótica.
} 
su cabeza cayó sobre un hombro, sus ojos se cerraron y una sonrisa de infinita beatitud, lánguida hasta lo doliente, se dibujó en sus labios... (602)

La música conduce a la muerte. ¿Pero no es acaso esta una muerte comparable a aquella que los franceses bautizaron como la petite mort?

Esta es la experiencia erótica máxima a la que pueden aspirar muchos personajes mannianos, incluido el payaso. El arte, en especial la música, equivale a Eros en cuanto llena ese vacío vital o provee de un modo transfigurado eso de lo que se carece y que tanto se anhela. El abandono a la belleza, a la fantasía desbordante de la literatura o a la efervescencia aturdidora de la música compensa la insatisfacción que surge a consecuencia de la negación de los propios impulsos y de la renuncia a las pasiones más profundamente humanas: la renuncia a Eros.

"Y sí, no hay duda de que yo era feliz», se dice a sí mismo el payaso (128). ¿Lo era? Su rutina solitaria lo satisfacía. ¿Aburrimiento? De vez en cuando, ¿quién no se ha aburrido nunca? Pero justo en esos momentos, en que un libro no basta, en que la fantasía se agota, en que la música calla, «te acosa un sentimiento de antipatía hacia todo el mundo y hacia ti mismo» (135). Lo invade un sentimiento de desasosiego que por tiempos se aplaca y por tiempos resurge. Contempla «a la gente de oficio y a los trabajadores, demasiado incapacitados espiritual y materialmente para el ocio y el deleite», pero «felices». Se acerca a la treintena y se tambalea su enérgica convicción de ser feliz, y, de vez en cuando, se siente «algo fatigado de tanta soledad». Le invade cierto malhumor «a causa de [su] falta de relaciones y de socialización» (135-136). ¿Qué hacer, pues? Piensa en los círculos sociales cercanos, pero reconoce que le son inaccesibles, que de ningún modo puede ser enteramente él mismo en ellos, que con nadie es posible compartir su mundo espiritual:

En definitiva: no había ningún círculo social concreto del que yo pudiera formar parte de una manera natural, y las relaciones que a veces se daban por azar eran raras, superficiales y frías... Por culpa mía, tal como no vacilaré en admitir, pues también en tales casos, impelido por un sentimiento de inseguridad, me mantenía reservado y con la desagradable conciencia de no poder decirle de forma clara, concisa y respetable ni siquiera a un pintor desastrado quién y qué soy en realidad. (136)

«Había roto con la "sociedad" y renunciado a ella». Ese «estar-para-sí», ese «aislamiento», esa «marginalidad», que tanto gozo le habían procurado antaño, empiezan a tambalearse. La vida pierde sentido. ¿Y ahora qué? «Ah, he sabido organizarme la vida a mi gusto! ¿Acaso no soy feliz? Es ridícula, esa pregunta; ridícula y nada más...» (137). No basta. Cuando cesa la música, cuando la literatura pierde interés, no queda nada. Ese vacío inconmensurable e insaciable tira de él hacia abajo. Lo lleva a desear ser una persona «normal», acaso trivial y frívolo, pero lleno de vitalidad. Luego pasa. Empieza a sonar la música y el vacío erótico se sacia. Pero vuelve. Toda vida es retorno y repetición. El zigzagueo emotivo 
nos persuade de que la renuncia no es un acto del todo voluntario, sino un destino, una fatalidad. ${ }^{9}$ Reflexiona:

Quizá lo que realmente me pasa es que yo he renunciado a esa «felicidad exterior»al retirarme del servicio a la «sociedad» y organizarme la vida «sin gente». Pero de que estoy satisfecho con ello, no se debe dudar. (139)

Para esta crisis sabe encontrar un consuelo; para la próxima, una distracción; para la siguiente, un narcótico, y así para las sucesivas... «Pero todo esto volvió de nuevo, volvió miles de veces en el transcurso de los meses y de los años».

Este retorno de lo reprimido, al igual que para el señor Friedemann, se produce en su mayor expresión a los treinta. Advertimos que a la insatisfacción o tedio vital se sigue inmediatamente el despertar erótico. Se fija en una morena de ojos negros de la que cree enamorarse, pero reconoce la imposibilidad de vivir o de ver correspondido y realizado su amor. La proyecta en un mendigo, otro marginado, que, frente al escaparate de un joyero, contempla absorto el refulgir centelleante de un aderezo de diamantes. El protagonista piensa, como si se desengañara a sí mismo: «Este hombre no llegará a formular claramente en su interior el deseo de poseer la joya, pues ya solo la mera idea de ese deseo constituiría una imposibilidad tan ridícula que lo convertiría en objeto de sus propias burlas» (142).

Como el pequeño señor Friedemann, va a la ópera y se sobresalta al descubrir a la joven dama en uno de los palcos. No desvía la mirada de ella en toda la noche $y$, muy a su pesar, parece acompañarla su prometido, caballero que irradia una gran seguridad de sí. Nuestro protagonista ha de conformarse con «contemplar tristemente desde la lejanía» (146), como mero espectador. (Lo mismo harán luego Tonio Kröger, Gustav von Aschenbach e incluso Hans Castorp).

¿De verdad se enamora? « ¿Acaso amaba — si se me permite plantear esta pregunta_, acaso yo amaba realmente a esa muchacha? Tal vez...» (150). Es solo una posibilidad, él mismo no está seguro. Sospecha que su amor puede ser un engendro de su vanidad o, mejor, «una simple excusa, una escapatoria y una forma de salvación». «iSí, todo eso es vanidad! ¿No me había tachado ya mi padre de payaso?», se dice. Se confiesa «demasiado vanidoso»-también lo era el pequeño señor Friedemann-y, sobre todo, se descubre a sí mismo que su mundo interior, aquella vida que se había organizado a su gusto, no basta: « ¡Ya no puedo más, soy infeliz, lo reconozco, y veo en mí una figura patética y

\footnotetext{
${ }^{9}$ Contrario al ascetismo pasional censurado por Nietzsche, ni el payaso ni el señor Friedemann eligen realmente, aunque ellos puedan creer que sí, su destino. Este espíritu de renuncia, con todas sus inhibiciones, está íntimamente ligado a su esencia, a lo que pueden. Por servirme de otra expresión nietzscheana: «No hay ningún "ser" detrás del hacer, del actuar, del devenir; [...] el hacer es todo» (La genealogía de la moral I, 13, p. 67). De otra parte, cualquier intento de transgredir ese espíritu de renuncia conduce irremediablemente a la perdición.
} 
ridícula!». Piensa en «sacarle partido literario al asunto» — iguiño del autor?-, pero se siente sin fuerzas. Intuye su hundimiento. Se ve próximo al abismo.

Es cierto que el payaso no sufrirá la humillación que hunde a Johannes Friedemann, no soltará los perros, pero la rebelión interior de todo lo reprimido, su inevitable retorno, lo llevan a simpatizar con la muerte. No se gusta, se siente ridículo: esa es la razón por la cual su mundo — en esencia interior- se desmorona y pierde sentido. Él lo sabe: «Solo existe una clase de infelicidad: perder la complacencia que uno tiene consigo mismo. Dejar de gustarse, eso es la infelicidad...» (151). Aunque quienes lo rodean admiran en silencio su vida ordenada y dispuesta a su gusto, no imaginan el vacío abismal que yace tras ese cielo entrañable en soledad. El comerciante Schilling, antiguo compañero suyo, le dice: «iPor todos los diablos, tú sí que has sabido organizarte bien la vida, muchacho! Con que independiente, ¿eh? ¡Libre! ¡En realidad tienes toda la razón, maldita sea! Solo se vive una vez, ¿verdad? En realidad, ¿qué demonios nos importa lo demás? Eres el más listo de los dos, tengo que reconocerlo. De hecho, tú siempre fuiste un genio...». Intenta parecer feliz y satisfecho de sí mismo... jen vano! No soporta «el asco que [le] suscita "todo eso"» (119). Piensa en la muerte, pero le falta heroicidad para ello. «Y es que no queda más remedio: hay que vivir». Su fatalidad es haber nacido distinto, haber nacido «payaso», esto es, con una sensibilidad y espiritualidad de artista, condición que le veda para siempre, por su excepcionalidad, por su inseguridad e imposibilidad de participar en la vida «real», por su vida solitaria, riquísima y exquisita, pero solitaria al fin... el amor.

\section{De la NOSTALgia eRótica De TONIO KRÖger AL EROTISMO DE LA MUERTE DE GUSTAV VON ASCHENBACH}

«Para el schopenhaueriano hay dos vías de liberación del encadenamiento del sexo: el arte y la santidad» (Kurzke 2004: 91). Y digo sexo, junto con Kurzke, porque así fue como entendió Thomas Mann la «voluntad» de Schopenhauer: la leyó en clave erótica. ${ }^{10}$ Solo a través del arte y de la santidad se detiene la rueda

${ }^{10}$ Para Thomas Mann, la esencia más profunda de la filosofía de Schopenhauer es el erotismo. La conmoción orgánica que le produjo su lectura «solo puede ser comparada con la conmoción que en el alma joven produce el primer conocimiento del amor y del sexo» (2014: 71). Los artistas siempre entienden una filosofía a su manera, «que es una manera emocional» (72). Puede que esta lectura erótica se viera mediada por la música de Wagner, la que tanto admiraba Thomas Mann: «Y así es como Schopenhauer fue "comprendido" por Wagner cuando, por así decirlo, este colocó su misterium erótico, el Tristán e Isolda, bajo la protección de la metafísica de Schopenhauer. Lo que de Schopenhauer influyó en Wagner, y en lo que este se reconoció, fue la explicación del mundo a partir de la "voluntad", del instinto, la concepción erótica del mundo (el sexo como "foco de la voluntad"), por la cual están determinadas la música del Tristán y su cosmogonía del anhelo. [...] Es en el amor, es en el sexo en donde con mayor fuerza se afirma a sí misma la voluntad» (71-72). En Relato de mi vida, declara: «Lo que me encantaba [...] era el elemento erótico 
de Ixión, se anula la voluntad y consigo cesa todo desear, incluido, desde luego, el deseo erótico. El artista, para Thomas Mann, tiene que ser un asceta, tiene que ser casto. «No creo que hoy en día se pueda ser un bon vivant y al mismo tiempo un artista», escribe a Kurt Martens el 28 de marzo de 1906 (apud Kurzke 2004: 91). La idea no es nueva. También Gustave Flaubert había encerrado en jaulas sus pasiones: «Llevo quince años largos trabajando como una mula. He pasado toda mi vida en esta obstinación de maniático, excluyendo y encerrando en jaulas mis otras pasiones» (carta a Louise Colet, 20-21 de marzo de 1852; 2014: 505). En otra carta de Flaubert, cartas que leyó por cierto Thomas Mann en su temprana juventud, se pone de manifiesto que el artista debe ser siempre espectador y nunca partícipe de la vida:

Tu peindras le vin, l'amour, les femmes, la gloire, à condition, mon bonhomme, que tu ne seras ni ivrogne, ni amant, ni mari ni tourlourou. Mêlé à la vie, on la voit mal ; on en souffre ou on en jouit trop. (Carta a su madre, 15 de diciembre de 1850, apud Vargas Llosa 1975: 105)

El arte, como ha sabido explicar inteligentemente Esteban Tollinchi, «conlleva la deshumanización del artista», deshumanización que conduce ineludiblemente a una «soledad radical»: «parecería que el artista debiera estar dispuesto a traicionar el amor, la vida y la humanidad en aras del arte» (1973: 61-63). Tonio Kröger intenta conciliar la disyuntiva vida-arte o espíritu-vida, la cual late en toda la obra manniana (pensemos en Los Buddenbrook y en El payaso), trasladando la disciplina de trabajo burguesa, la ética de la Leistung, a la producción artística. Comenta Tollinchi:

En Tonio la disciplina y la rutina burguesa se transforma en el trabajo del artista, que fundamentalmente se concibe como ascetismo y negación de la naturalidad. La impasibilidad necesaria lo convierte en simple espectador y observador de la vida, no en participante. (Tollinchi 1973: 63)

A esta impassibilité flaubertiana se entregan con todo su ardor juvenil Tonio Kröger y Gustav von Aschenbach, y esto habrá de pasarles factura. Tonio Kröger: «Trabajaba no como alguien que lo hace para vivir, sino como alguien que no desea sino trabajar; porque se desprecia como ser viviente, desea ser considerado únicamente como creador y se porta en lo demás tan gris e insulso como un actor sin afeites ni pinturas que nada es cuando vive fuera de escena. Trabajaba en silencio, aislado, invisible y henchido de menosprecio hacia aquellos seres pequeños cuyo talento» ignora «que las grandes obras solo pueden surgir bajo la presión de una vida difícil», «que quien vive no trabaja y es preciso morir para ser un auténtico creador» (247). Gustav von Aschenbach estaba siempre «excesivamente ocupado [...], gravado en exceso por el imperativo de producir, y demasiado reacio a la distracción» (466). Esclaviza la sensualidad mediante una

y místicamente unitario de esta filosofía» (1984: 26). De Schopenhauer aprendió que incluso el amor más sublime es esencialmente sexual. 
autodisciplina férrea que lo aleja de «lo trivial» y «lo excéntrico», y lo lleva a renunciar a todos los placeres de la juventud. La «extrema necesidad de discliplina» de Aschenbach es herencia paterna, la misma «espiritualidad glacial» que hereda Tonio Kröger. Su palabra predilecta es «resistir» (470), siempre con entereza, siempre manteniendo la compostura como san Sebastián, que conserva su bella figura pese a las flechas que lo traspasan: transido de dolor, mas sonriente. «Gustav Aschenbach era el poeta de todos los que trabajan al borde de la extenuación, curvados bajo una excesiva carga, exhaustos, pero aún erguidos» (472). Él mismo anota que «casi todo lo grande que existe, existe como un "a pesar $\mathrm{de}^{\prime \prime}, \mathrm{y}$ adquiere forma pese a la aflicción y a los tormentos, pese a la miseria, al abandono y a la debilidad física, pese al vicio, a la pasión y a mil impedimentos más» (471). A pesar de la pasión, a pesar de Eros, a pesar de su renuncia, a pesar de su retorno, a pesar de las recaídas, a pesar del tormento, a pesar del abandono... Gustav von Aschenbach es el artista del «a pesar de». ${ }^{11}$

Con todo, y pese al espíritu de renuncia encarnado en estos personajes, requisito ineludible del artista, ${ }^{12}$ laten profundas angustias y reiterados «a pesar de». Siempre retorna a ellos de algún modo todo ese contenido prohibido y la nostalgia de entregarse a la seducción, tanto erótica como tanática, que este representa. Si bien resultaría simplista despachar a Aschenbach como un Tonio viejo, estamos ante una faceta más y con un grado de madurez distinto de un mismo ser que asume máscaras diversas y que siempre remite, en el fondo, a

${ }^{11}$ Cumple decir que el propio Thomas Mann asumió esta rigurosa disciplina de trabajo. Trabajaba todos los días de la semana, incluso en vacaciones. Cuenta Kurzke: «La tensión es terrible. Cada mañana un "pasaje", no es posible hacer más. Tal como asegura Mann en 1907, para no salir corriendo ante un ritmo semejante y terminar lo que se ha empezado se requiere una paciencia, una obsesiva terquedad, una autosubyugación de la voluntad que a menudo tensa los nervios hasta hacerlos gritar. [...] Escribir menos de treinta líneas al día genera insatisfacción. [...] El trabajo es necesario por el bien de la salud psicológica [...] “En realidad, uno solo se siente a sí mismo y sabe algo de sí cuando trabaja. Los períodos intermedios son espantosos". Espantosas son también las épocas de crisis, cuando el trabajo se queda bloqueado. [...] Cuando no logra avanzar, Mann transmite su mal humor a todos los que le rodean. Y cuando acaba algo, sin pausa alguna, normalmente al día siguiente se pone manos a la obra con los trabajos preliminares para la tarea siguiente. Lo que se llegó a acumular en el transcurso de su vida a fuerza de tan infatigable actividad, contando cartas y diarios, debe de rondar las cinco hojas diarias, o sea, mil ochocientas al año y, en sesenta años creativos, más de cien mil apretadas páginas: uno se queda con la boca abierta. [...] Thomas Mann no vive por vivir, sino para escribir» (2004: 186-196).

${ }^{12}$ Encontramos otro ejemplo en Alteza real (1909). El artista Alex Martini gana un torneo poético con una oda al gozo de la vida, pero luego confiesa a Klaus Heinrich: «El goce de la vida nos está prohibido, rigurosamente prohibido, no nos lo ocultamos, y bajo el goce de la vida no entendemos solo la felicidad, sino también las preocupaciones, también la pasión; en una palabra, toda relación seria con la vida. [...] La renuncia es nuestro pacto con las musas; en ella descansa nuestra fuerza, nuestra dignidad, y la vida es nuestro jardín prohibido, nuestra gran tentación, a la cual a veces, pero nunca para nuestro bien, sucumbimos» (175). Es elocuente que sea autor de Evohé, título que evoca el grito de embriaguez e invocación a Dioniso, y Vida de santidad, que remite al ascetismo del artista, al lado apolíneo. 
unas mismas pulsiones íntimas, a la «papilla primigenia». ${ }^{13}$ Se trata de una misma angustia, siempre erótica, la misma que también atenaza y oprime al pequeño señor Friedemann y al payaso, personajes que se ven impedidos, no únicamente por razones artísticas, sino más bien íntimas, personales y vitales, a vivir el amor, el erotismo. Les está íntimamente vedado y quien opta por la transgresión nunca termina bien parado, sucumbe sin remedio al abismo. También la inhibición perpetua se habrá de pagar caro, y eso lo veremos. La renuncia, que nunca es absolutamente voluntaria, es condición tanto del artista casto (Tonio Kröger, Gustav von Aschenbach, Adrian Leverkühn...) como del burgués práctico (Thomas Buddenbrook, el pequeño señor Friedemann, Hans Castorp...). Pesa sobre todos la ominosa condición mefistofélica que ha de admitir Adrian Leverkühn para triunfar artísticamente (y, en el fondo, en su propia vida): «Liebe ist dir verboten, insofern sie wärmt. Dein Leben soll kalt sein - darum darfst du keinen Menschen lieben» (Doktor Faustus XXV, 385), esto es, «El amor, en la medida en que calienta, te está vedado. Tu vida ha de ser fría -y así quedas privado del amor humano» $\left(351^{14}\right)$. Coincido con Tollinchi cuando advierte que la incapacidad de amor no es resultado del pacto diabólico, sino que antecede la propia consagración del artista y responde a su naturaleza innata. ${ }^{15}$ La renuncia a Eros, su imposibilidad, es congénita. También se torna imperioso hacer extensible la siguiente afirmación de Tollinchi sobre Leverkühn a los demás personajes mannianos: «la resistencia de Adrián a lo erótico no se debe a inocencia prolongada ni a pudor ni a beatería» (1970: 73). Late más bien un temor, un miedo al abismo, el miedo a derrumbar todo el castillo vital erigido con tanto esfuerzo y dedicación. Este castillo puede ser simplemente vital, una vida organizada al gusto propio como hacen los en esencia jóvenes Johannes Friedemann y el payaso, burgués, como Thomas Buddenbrook, o artístico y público, como prevé que habrá de hacer Tonio Kröger y harán Gustav von Aschenbach, Adrian Leverkühn y el propio Thomas Mann.

El artista, así, casto y espectador evidioso desde la distancia, se convierte en un ser marginal, en un outsider. De ahí su soledad radical. ${ }^{16}$ El arte, vía

13 Thomas Mann veía la continuidad entre ambas obras, según comentaba a Félix Bertaux en carta en 1923: «Esta historia [Muerte en Venecia] es en buena cuenta el Tonio Kröger narrado en una etapa ulterior de mi vida» (apud Karst 1974: 105). Ambas narran lo que en otra carta llamaría «la tragedia de la genialidad» (104).

${ }_{14}$ Modifico levemente la traducción citada.

15 «Está claro que la incapacidad de amor y de entender el instinto no resultan de una consagración en lo demoníaco mediante el pacto. No siendo el demonio más que la capacidad de reforzar y exagerar lo que ya se era por naturaleza, esa explicación tiene que ser descartada. En efecto, la infancia de Adrián revela ya su incapacidad afectiva y sentimental» (1970: 72).

${ }^{16}$ Cumple decir que el tema de la soledad radical del artista es recurrente en la literatura decadentista. En gran medida, la separación del mundo y el desarrollo de la vida interior se entronca con las reflexiones propias de la «novela de artista» (Künstlerroman), anticipadas por los románticos alemanes y entronizadas por decadentistas como Joris-Karl Huysmans, centradas en el problema del arte y del artista en el mundo moderno: la idea de que en el mundo «real», en el 
schopenhaueriana para liberarse de la tiranía del sexo, ha de basarse en la renuncia, en el sacrificio y en el sufrimiento: es el resultado de una vida difícil. Lo declara sin ambages Lizaveta a Tonio:

Pues bien, el efecto purificador y santificador de la literatura, la dominación de las pasiones por el conocimiento y la palabra, el poder redentor del lenguaje, el espíritu literario como la manifestación más noble del alma humana, el literato como hombre perfecto, como santo... (255; énfasis mío)

Además de referir a la literatura rusa, ${ }^{17}$ sin duda hace referencia al erotismo reprimido por Tonio.

And yet, and yet... El destino del artista podrá condenarlo a ser distante, a parecer frío, pero nunca llegará a ser genuinamente inhumano: «Tonio Kröger resulta a la postre profundamente humano, pues, ¿cómo negar la humanidad a un ser cuya esencia es la preocupación misma?» (Tollinchi 1973: 64-65). Tras la eminencia y la frialdad exterior del artista, late una soledad profunda y un erotismo nostálgico, anhelante. Su preocupación surge, en principio, por la lacerante escisión simbolizada por la dicotomía norte-sur, representada por padre-madre, esa oposición de «espiritualidad glacial» $\mathrm{y}$ «sensualidad ardiente» (246), condensada en la hibridez de su nombre: Tonio, de origen latino (el hermano de la madre se llama Antonio) y Kröger, germánico. Su vida desgarrada se intuye desde «aquel nombre compuesto de sonidos meridionales y septentrionales, aquel nombre burgués, de sabor exótico» (247). La misma pugna onomástica, ese intento de conciliar dos mundos espirituales enfrentados, se produce recurrentemente en la obra manniana: Paolo Hofmann (La voluntad de ser feliz, 1896), Detlev Spinell (que los personajes confunden con el apellido italiano Spinelli en Tristán, 1903), Axel Martini (Alteza real, 1909), Adrian Leverkühn y Serenus Zeitblom (Doktor Faustus, 1947), Félix Krull (Confesiones del

mundo burgués o materialista, el arte no tiene sentido ni utilidad ni se puede comprender ni valorar en sus auténticas dimensiones. Con todo, me parece que detrás de estos personajes mannianos late algo mucho más profundo que los constriñe a tal soledad, en la que logran encontrar, sí, su cielo, su amor y su canción — por servirme una vez más del Lied de Mahler-, pero que en determinado momento ello se torna insuficiente y desemboca en un anhelo íntimo de complicidad. Lo anticipa de algún modo el duque Des Esseintes en $A ̀$ Rebours, quien intenta construirse su propio mundo y organizarse su propia vida en soledad como una exquisita y refinada obra de arte, y al final fracasa precisamente por el vacío que a la larga produce el peso inevitable de su soledad interior. Aun así, me parece que las inquietudes de los personajes mannianos son más profundas —acaso más humanas - y están estrechamente ligadas a la renuncia erótica, renuncia que no se produce en Des Esseintes ni en general en los decadentistas.

${ }^{17}$ Sobre el escritor ruso del siglo XIX, escribe Yuri Lotman: «En la cultura de la Rusia posterior a Pedro el Grande, el escritor ocupó el lugar que la etapa precedente le asignaba al santo —al predicador, al hombre entregado con abnegación y al mártir. Esta asociación descansaba sobre la fe en la fuerza especial de la palabra y el íntimo vínculo de esta con la verdad. Como el santo, asimismo el escritor debía mostrar con su entrega abnegada su derecho a hablar en nombre de la Verdad Suprema» (1998: 162). Esta es la ideología que subyace en el comentario de Lizaveta y su respuesta a las inquietudes de Tonio Kröger sobre la inutilidad de la literatura. 
estafador Félix Krull, 1954)... La escisión es a menudo genética: al igual que el Thomas Mann de carne y hueso, hijo de un burgués de Lübeck y una germanobrasileña, muchos personajes comparten genealogía: padre alemán, representante burgués del norte (rigidez, dignidad, autodominio, sensatez, ambición, diligencia, trabajo, éxito, elegancia personal e intelectual, bonhomía, solemnidad...) y madre sureña (arte, belleza, pasión, sensualidad, música, fantasía...). Así Paolo Hofmann, Tonio Kröger y Gustav von Aschenbach. Aunque no queda claro el origen de los padres del payaso, sí se sabe que el padre es el típico burgués, que ve el arte como una «payasada» — de ahí el sobrenombre del hijo-, y la madre, aficionada a tocar al piano los Nocturnos de Chopin y de contar historias fantasiosas al hijo. Los personajes representan, así pues, la convergencia de dos mundos opuestos y el profundo conflicto interno que ello produce. Se debaten entre dos mundos irreconciliables. Para Tonio Kröger resulta igual de problemático haber nacido artista que haber nacido burgués: por un lado, su riqueza interior y el conocimiento no le sirven de mucho en la vida práctica, sino que contribuyen a su soledad radical; por otro, el afán de representación, tan burgués — como revela Thomas Buddenbrook—, le prohíbe ceder a la seducción de la ardiente sensualidad. Ha de conformarse con contemplar desde las sombras las alegrías de la vida, siempre con nostalgia y añoranza, con ser, al decir de Kurzke, un «espíritu sufriente que contempla anhelante la vida desde la barrera» (2004: 140).

Desde el inicio del relato, se remarca el contraste de vitalidad entre Tonio y Hans Hansen, vitalidad representada siempre en la obra manniana por rubios triviales y felices. La mirada de Hans es penetrante y segura; la de Tonio, ensombrecida, triste y tímida. Hans es sumamente bello y bien proporcionado; Tonio, extraordinariamente delicado. El andar de Hans es siempre seguro y acompasado; el de Tonio, irregular y desmañado. Ello explica, en parte, el enamoramiento: «Tonio quería mucho [liebte] a Hans Hansen [...] Le quería, primero, porque era guapo, y luego, porque en todos los aspectos le parecía como su viva antítesis y antípoda» (229-231). El verbo en alemán es lieben (la traducción más literal de «liebte» sería «amaba»), por lo que va más allá del cariño fraternal y se sitúa legítimamente en el ámbito erótico, entendido este como un fuerte vínculo espiritual, físico y emocional. Tras ese amor, late el deseo de ser normal —deseo que ya vimos en el payaso-, esto es, de conciliar norte y sur, espíritu y vida:

Sintió una especie de anhelo [...], un anhelo lleno de envidia que le invadía el pecho y lo quemaba. «iQuién tuviera unos ojos tan azules como los suyos - pensaba-, y pudiera vivir, como tú, en tanto orden y tan dichosa comunión con todo el mundo! Tú siempre estás ocupado en cosas que todos respetan y consideran útiles. [...] Ser como tú...» (232)

Sí, pero solo en parte. Late además muy intensamente un erotismo genuino. Dice el narrador: 
Nunca intentó ser como Hans Hansen, y tal vez este deseo nunca llegó a ser sincero. Sin embargo, anhelaba ardientemente verse estimado por Hans tal como era, y pretendía conseguir ese cariño a su modo, un modo lento e íntimo, resignado, pasivo y melancólico, con una melancolía, no obstante, capaz de arder más profunda, violenta y corrosivamente que cualquier pasión que pudiese nacer de su apariencia meridional. (232)

El propio Hans llega a reconocer ese «afecto poco común, intenso y tierno hacia él» que anida en Tonio. Lo valora y a la vez le repele, le chirría lo sensual, lo meridional que resuena en su nombre: «Te llamo Kröger porque tienes un nombre tan absurdo, ¿sabes...? Perdona, pero no lo soporto, Tonio. En realidad, ni siquiera es un nombre... Claro que tú no tienes la culpa, ¡no faltaba más!» (235). Esa naturaleza meridional cifrada en el nombre, ajena al mundo de Lübeck, lo margina: «Sí, quisiéralo o no, era un tipo singular en todos sus aspectos, y estaba solo y excluido de la vida ordinaria y corriente, aunque no fuese uno de esos gitanos en carretas verdes, sino el hijo del cónsul Kröger, de la familia de los Kröger...».

Dos años después aparece otra rubia en su camino: Ingeborg Holm. La pobre caracterización de la joven, en comparación con la de Hans Hansen, nos persuade un poco de que el supuesto enamoramiento de Tonio no es genuino, que ella simplemente representa la espontaneidad de la vida que tanto le atraía de Hans Hansen, además de tener su misma mirada, sus ojos risueños y azules. ${ }^{18}$ «La había visto miles de veces» (237), dice el narrador, y siempre le había resultado indiferente. Solo en una ocasión en que la vio sonriente y llena de vida creyó experimentar lo que interpreta como amor. Él anhela ese amor, que para la sociedad en que se movía el señor Friedemann supone la «máxima felicidad que la vida puede brindarnos». Por eso lo acoge y se entrega a él, en silencio y desde la distancia, anhelando ese ímpetu de jovialidad, anhelando «ser rico y estar lleno de vida» (238). Inge representa la vida «normal», esa felicidad «exterior» que a la larga también deseaba experimentar el payaso. Representa el norte, su condición de «burgués», amenazada por la sangre sureña que corre por sus venas y que se le muestra a cada paso, incluso en su pareja de baile, muchacha de «ojos oscuros, de mirada grave y romántica» (240). Él sabe que todo lo que Inge representa le es lejano e inaccesible, que él pertenece a otro mundo en que está solo y «excluido de los demás» (243). Este amor es apenas una «llama pura y casta» (244), como si tuviera puesto una sordina, y que se complace en su mera existencia, como si se esperara de él que a los dieciséis todo joven hecho y derecho debiera experimentar amor por alguna muchacha para así participar de la felicidad «exterior» de la vida. «Y, sin embargo, era feliz», dice el narrador (243). El gozo

${ }_{18}$ Volveremos a ver un paralelismo erótico similar en Hans Castorp y Pribislav Hippe-Clavdia Chauchat. Resulta curioso que las manifestaciones homoeróticas explícitas en la obra manniana siempre sean figuras de muchachos y hombres jóvenes. Tal vez se deba a que el propio Thomas Mann las vivió así. En cualquier caso, estos personajes, una vez superan la pubertad, desplazan esta atracción homoerótica hacia figuras femeninas, que en el fondo recuerdan o remiten a esa vivencia primigenia. 
que le supone la nostalgia, así como la rapidez con la que se le pasa el enamoramiento, el modo en que esa llama se extingue imperceptiblemente, están muy lejos del profundo dolor que los insignificantes desplantes de Hans Hansen le causan, lejos de aquellos continuos nudos en la garganta, de los pequeños arrebatos de celos que lo atenazaban, y de todo eso que lo llevaba a identificarse con un rey que llora, escena que lo conmovía de un modo especial hasta producirle sacudidas fulminantes.

El tiempo pasa. La sangre materna lo conduce al sur, donde se entrega a los placeres de la carne por un tiempo sin mayor satisfacción, siempre «vacío de amor» —en esto se aleja, por cierto, de Gustav von Aschenbach y de casi todos los personajes mannianos, así como del propio autor. Y se vuelca, como ya hemos dicho antes, al trabajo excesivo. La gran crisis, una vez más, se produce a los treinta, cuando el peso de la renuncia se agrava: «Le aseguro», confiesa a Lizaveta, «que muchas veces me siento mortalmente cansado de representar lo humano sin tener parte en lo humano...» (252). El artista, explica, está excluido de la sensación: «iSe acabó el artista en el momento en que se haga humano y empiece a sentir!» (251). El artista ha de ser frígido y «extrahumano». (Pensemos en Adrian Leverkühn, que siempre tiene frío). Cuando siente, cuando irrumpe la pasión o lo humano, muere: así Gustav von Aschenbach e incluso la Gabriele del Tristán. «Yo amo la vida», confiesa Tonio, «yo amo la vida...» (257). «La literatura cansa» (256), anhela «el afán furtivo y abrasador de los goces de la trivialidad» (257). Anhela la vida normal y corriente, aquella espontaneidad que le fascinaban de Hans Hansen y de Ingeborg Holm. Por eso siente «náuseas del conocimiento» (255), pues este no le sirve de nada para la vida práctica, sino que contribuye a su perpetuo aislamiento. ${ }^{19}$ Luego de escucharlo largos minutos, Lizaveta dictamina:

Pues bien, la solución es que usted, ahí sentado, es, simple y llanamente, un burgués. [...] Es usted un burgués descarriado, Tonio Kröger, un burgués que ha errado el camino. (260)

Tonio Kröger intenta resolver la antinomia vida-arte viajando a la patria nórdica. No soporta ya la sensualidad sureña, la bellezza italiana: «En fin, que no quiero, renuncio. Toda aquella bellezza me pone nervioso» (260). En Lübeck, pone mayor cuidado que de costumbre en su aseo personal —imposible no recordar la obsesión por el aseo de Thomas Buddenbrook—, se viste de burgués: «Se miró detenidamente en el espejo y de repente se sintió más seguro tras su máscara» (264). Se dirige inquieto a su casa natal, esa casa tan gris y seria como trescientos años atrás, recuerda al padre ya muerto y teme una reprimenda suya. Contempla el mundo de la infancia, sus orígenes, y enseguida le basta. La extraña visita a su

19 «La literatura, como símbolo de consciencia, puede ser más perjudicial que útil, pues olvida que la opacidad es un elemento necesario para la vida; mucho más en la vida práctica, como lo revela la incapacidad de bailar de Tonio» (Tollinchi 1973: 69). Reconoce «el abismo entre el mundo de la vida y el mundo de la literatura. [...] El presente diálogo ha expuesto en forma semidramática el conflicto del artista burgués a principios de siglo, el conflicto del joven Mann, como también de todo artista joven» (72). 
ciudad natal acaba con un interrogatorio de parte de un policía que lo confunde con un criminal, lo cual en el fondo él acepta, pues ser artista es ser un transgresor. Se marcha. Aspira el aire del mar y siente una infusión de vida. Llega al balneario de Aalsgaard y allí se pierde en el dulce olvido que le produce la contemplación de la inmensidad del mar. «Y de pronto sucedió lo siguiente: Hans Hansen e Ingeborg Holm atravesaron la sala» (281). Entran los dos cogidos de la mano y él se estremece, invadido por una dolorosa nostalgia. Se aleja «como si anduviese por sendas prohibidas» (283) y se resigna a contemplarlos desde la distancia, oculto tras una vidriera. Anhela acercarse a ellos, decirles algo, pero no tiene el valor para hacerlo. Sabe que ellos nunca lo comprenderían, que incluso podrían burlarse de él, pues ellos no hablan su lenguaje. «¿Has leído ya el Don Carlos, Hans Hansen, como me prometiste que harías [...]? ¡No lo hagas! [...] ¿Qué te importa a ti un rey que llora porque está solo?» (286). Ese rey es Tonio Kröger, el eterno incomprendido. ${ }^{20}$ Sabe que de nada serviría volver a empezar de nuevo, para intentar ser una persona normal y corriente, «de acuerdo con Dios y con el mundo», y vivir en «dichosa vulgaridad, libre de la maldición del conocimiento y de la tortura de la creación artística», pues «todo volvería a suceder tal como ha sucedido». Sería como un eterno retorno. Lo había dictaminado el narrador de El pequeño señor Friedemann: «Tenía que ser así, era su destino». Está condenado a observar, a ser siempre espectador y nunca partícipe de la vida que tanto ama y anhela, a envidiar desde la distancia. Descubre que es imposible reconciliar los «extremos opuestos», que ha de renunciar a «los rubios, los alegres, los felices», que solo le resta sollozar «de remordimiento y de añoranza» (289-291). Escribe con razón Tollinchi:

Con el gemido se presenta en Mann el tema de la renuncia y de la resignación, que tanta importancia cobrará en el personaje de José o el de Goethe. Llora por la ética burguesa que ha perdido y que ha ofendido, llora por el amor que le está prohibido, por su amor inútil que nunca podrá alcanzar en el reino de la vida. (Tollinchi 1973: 74-75)

Siempre habrá de renunciar al amor, de rehuir la pasión y el patetismo. Su amor es, ante todo, resignación y nostalgia:

${ }^{20}$ Esta incomprensión, esta distancia abismal entre quien tiene una vida interior rica y plena, pero que es ajena a los demás (pensemos, además de Tonio, en el señor Friedemann y el payaso), y el deseo ocasional de quebrantarla y encontrar la posibilidad de compartir ese mundo interior con otro, me incitan a citar la siguiente reflexión de Kurzke referida a Thomas Mann: «No le resultaba fácil explicarse a los demás, o, al menos, no los abismos de su alma. Sin duda, mantenía a la gente lejos de él, y eso podía causar la impresión de arrogancia, como si no necesitara a nadie. Pero ¿no hay también cierta forma de distanciamiento que, en realidad, constituye una petición de proximidad? ¡Una forma de implorar que alguien gane para la causa de la humanidad a quien, sin querer, se ha vuelto un témpano de hielo, tal como consiguiera hacerlo Paul Ehrenberg? [...] Vista desde fuera, su vida parecía construida tan hábilmente que no había nadie que sintiera compasión por él. ¡Y, sin embargo, sufría! Sabemos por sus diarios hasta qué punto sufría» (Kurzke 2004: 327). 
Y la nostalgia es el sentir que nunca quiere llegar a término, que no puede cumplirse porque su esencia consiste precisamente en la distancia, la separación, la infinitud de la insatisfacción. [...] Tonio desea la plenitud del amor, pero le faltan las esperanzas de que se cumpla, como también la disposición interior para ello. El amor se presenta solo como una posibilidad, pero una posibilidad irreal, con la que no se cuenta [...] Por lo pronto, este amor que consiste de «nostalgia, de envidia melancólica, de un poco de desprecio y de una felicidad totalmente casta» le asegura a Tonio la solidez y la fuerza de su obra. (Tollinchi 1973: 77-79)

Sin esa nostalgia vital, en el fondo erótica, puede que no hubiera alcanzado «la solidez y la fuerza de su obra». El final es triste y a la vez esperanzador. Si bien es resignado, augura un futuro prometedor, imposible sin los avatares expuestos. La dominación de las pasiones por medio de la palabra, la cual proclamaba Lizaveta, es la condición que debe asumir el artista. La renuncia vital supone todos esos «a pesar de» que dignificarán a Aschenbach. Sin las vivencias de un Tonio Kröger, vivencias tanto literarias como claramente autobiográficas, no hubiera sido posible un Gustav von Aschenbach. ${ }^{21}$

«Toda vida es retorno y repetición», nos recuerda siempre Thomas Mann. «Las pasiones reprimidas, como otros elementos de la naturaleza, como el aire, el agua y el fuego, cuando son impelidos hacia el punto de presión máxima suelen hallar una válvula de escape en el lugar donde nunca se esperaba que cediera», escribía Stefan Zweig refiriéndose a Balzac (2019: 65) y así podemos introducir Muerte en Venecia (1912), máxima expresión de ese motivo fundamental que da cohesión a toda la obra manniana. Así lo presenta el autor a los estudiantes de Princeton en la citada conferencia On Myself:

Una vez más, mi tema fue la devastadora irrupción de la pasión, la destrucción de una vida formada, controlada de forma en apariencia definitiva, privada de su dignidad y empujada al absurdo por el «Dios extraño», por Eros-Dionisos. (Mann 2016a: 77)

${ }^{21}$ En Tonio Kröger se reelaboran las dos vivencias amorosas del joven autor: su primer amor, Armin Martens, compañero de escuela, y su amigo Paul Ehrenberg, que fue su gran amor de juventud, amor que, según escribe en su diario tres décadas después, nunca volvería a sentir por nadie. Tradicionalmente se han identificado ambos jóvenes con Hans Hansen e Ingeborg Holm respectivamente, si bien hay rasgos que se entremezclan: por ejemplo, a Hans Hansen le gustan los libros de caballos y Paul era pintor de caballos, y Thomas y Armin tomaron clases de baile juntos, como Tonio e Inge. El amor a Paul Ehrenberg nunca fue realmente correspondido, si bien la cercanía y algunos gestos lo llevaron a anotar: "Yo le amé, y fue una especie de amor correspondido» (diario, 13 de septiembre de 1919, apud Kurzke 2004: 155). Su amistad tenía algo de flirteo - en realidad Paul flirteaba con todas, lo cual dolía al joven Thomas; ello se recrea literariamente en Un instante de felicidad (1904)-, pero, hasta donde se sabe, fue siempre casta y distante en sentido erótico. Dieciocho años después, al contemplar un apuesto joven durante unas vacaciones, escribiría Thomas Mann en su diario: «Tonio Kröger, Tonio Kröger. Siempre es lo mismo...» (24 de julio de 1919, apud Kurzke 2004: 398). 
Es el artista que ha renunciado toda su vida al amor y a la vida «normal», esa que tanto anhela Tonio Kröger pero que al mismo tiempo le está vedada, que ha renunciado a los placeres de la juventud, que ha ordenado la vida a su gusto, como el payaso, y triunfa. Es un artista en edad madura que ya cuenta con una exitosa trayectoria a sus espaldas, trayectoria que ha forjado gracias a la férrea disciplina de trabajo antes expuesta, a esa «ética del logro» o de la Leistung. Es también el artista de la forma, el perfecto apolíneo: Apolo es el dios de la distancia y de la lejanía, nos dice Thomas Mann en su ensayo sobre Schopenhauer, y, por tanto, de la soledad.

Para subrayar el parentesco espiritual entre Tonio Kröger y Gustav von Aschenbach, es preciso decir que ambos personajes comparten: «la renuncia a las tendencias naturales» (Tollinchi 1973: 83); «la aspiración de acercamiento a los demás» (85); la juventud entregada al espíritu; la rigurosa ética de trabajo y la falta de vida que de esta resulta; la necesidad de viajar, uno al norte y el otro al sur; la nostalgia, el primero de amor y vida, el segundo de amor y muerte. Importa que nos detengamos en la compartida necesidad de viajar. Si Tonio Kröger necesita retornar a su mundo paterno y reencontrarse con su esencia burguesa y todo lo que esta implica, Gustav von Aschenbach, que ya ha vivido toda una vida de orden, pulcritud, trabajo, contención y autodominio, se siente llamado por el sur, por ese mundo sensual y ardiente que le urgía a Tonio aplacar. Es cierto que algo los distingue: Aschenbach no se entrega a la lujuria ni vive hasta el exceso la experiencia sureña como sí llega a hacer Kröger en su temprana juventud. En este sentido, se produce un quiasmo: cada uno, urgido por la imperiosa necesidad de reconciliar los mundos enfrentados que lo escinden - herencia paterna versus herencia materna, burguesía versus arte-, ha de esforzarse por encontrar un saludable justo medio y se entrecruzan en el proceso, el uno en busca de un norte que le brinde el orden necesario para producir la obra de su vida y apague su sensualidad nostálgica, el otro seducido por el sur, cuya sensualidad había negado durante toda su vida para lograr producir tal obra y luego se ve apremiado a recuperar. Sin el viaje de Kröger al norte no hubiera sido posible un von Aschenbach. He ahí la continuidad de estos dos seres escindidos. No es que Aschenbach sea un Kröger envejecido, pero sí es lo que aguarda al joven artista que, a consecuencia de su genialidad o excepcionalidad, se ve compelido a la renuncia perpetua a participar de la vida y encierra las pasiones en jaulas, como Flaubert, o encadena los perros en el sótano, como Thomas Mann: el retorno de lo reprimido. «Toda vida es retorno y repetición».

Algo más da cierto sentido de continuidad entre ambos personajes. ${ }^{22}$ Si bien Aschenbach carga la mano por el ascetismo y la disciplina de trabajo burguesa,

\footnotetext{
${ }^{22}$ Que comparten, por cierto, rasgos físicos como la «cabeza ladeada»: «Importantes destinos parecían haber discurrido por esa cabeza que tendía a ladearse con aire de sufrimiento», se dice de Aschenbach (475). Al menos tres veces se hace mención de la «cabeza ladeada» de Kröger: «Con las cejas algo torcidas y fruncidas, los labios redondeados para silbar y la cabeza ladeada, miraba a la lejanía» (229), «silbando con indiferencia, ladeando la cabeza y mirando a la lejanía»
} 
reprimiendo las pasiones y atemperando la calidez de su sangre, sí se produce, en realidad, cierta conciliación entre ambos orbes antagónicos: «La fusión de un sentido del deber austero y escrupuloso con impulsos más oscuros y fogosos dio origen a un artista, a ese peculiar artista» (469). El artista se origina a partir de la fusión de lo apolíneo y lo dionisíaco de la que hablara Nietzsche para explicar el origen de la tragedia griega. La bella apariencia, la forma apolínea, se enfrenta al fondo dionisíaco y lo transfigura, lo convierte en algo superior, en arte. Sin ese poder transformador del arte, sin ese trabajo apolíneo de embellecimiento del fondo pulsional caótico, el hombre perecería, pues no sería capaz de lidiar consigo mismo. El hombre necesita el arte para no perecer por la verdad. Thomas Mann nos enseña en su ensayo sobre Schopenhauer que los artistas siempre entienden la filosofía a su modo, que siempre es un modo emocional. Así, el fondo sufriente, carente de toda esperanza y sentido, esa verdad cifrada en la sabiduría silénica a la que se enfrentaron los griegos, según Nietzsche, para transfigurarla a través del arte, se transforma aquí en Eros. El trasfondo caótico que supone Dioniso en El nacimiento de la tragedia es traducido en Muerte en Venecia en estricto sentido erótico. Una vez más, nuestro autor lee a los filósofos en clave erótica. La bella forma del clasicismo apolíneo - la Novelle exhibe, por cierto, pasajes escritos en hexámetros perfectos - lograda gracias a una férrea disciplina de trabajo, a la Leistungsethik, ordena ese mundo subterráneo regido por un «Dios extraño», Eros-Dioniso, esto es, retiene bien encadenados los perros en el sótano. Este era, en el fondo, el deseo íntimo de Tonio Kröger y seguramente con el tiempo lograría llevarlo a cabo. Pero el ya maduro Gustav von Aschenbach olvida que el clasicismo de cuño winckelmanniano viene atado al erotismo, ${ }^{23}$ que

(244), «con la cabeza ladeada, escribió...» (264). Otro importante guiño, a la vez autobiográfico, es la producción literaria del joven Aschenbach: «... el joven artista había embelesado sin tregua a los lectores de veinte años con sus cinismos sobre la dudosa esencia del arte y del quehacer artístico mismo» (473).

${ }^{23}$ Anota Rosa Sala: «Winckelmann era lo que en aquellos tiempos se llamaba un "hombre de gusto italiano", es decir, homosexual. En su época, el público, no iniciado en su secreto, advertía el pathos de sus descripciones y compartía su vigor entusiasta, aunque no percibía, más que acaso inconscientemente, el erotismo subyacente a sus palabras. En general, todo parece apuntar a que el sueño helénico de Winckelmann, con sus griegos libres y bellos, fue en gran medida un extraordinario ejercicio de sublimación erótica [...] Así, se da la paradoja de que ese mismo ideal frío, estoico y espiritualizado de la belleza clásica que había inventado Winckelmann -la apoteosis del ser humano en el arte bello- era un frasco opaco que contenía, bien encerradas en su interior, unas pulsiones profundamente sensuales que solo asomaban ocasionalmente a través del fervor de su lenguaje» (2007: 222-223). Recordemos que Aschenbach ansía una vuelta al clasicismo y se muestra, en muchos sentidos, émulo de Winckelmann. Más adelante, Sala añade: «Por fin, lo dionisiaco, entendido como aquello largamente reprimido y controlado por la sociedad, puede empezar a asomar de nuevo entre la blancura idealizada de las estatuas y vengarse de la tradición erudita occidental encarnada por el profesor Aschenbach de La muerte en Venecia de T. Mann. Por fin parece abrirse por completo el frasco cerrado que Winckelmann había puesto en circulación, permitiendo que las pulsiones secretas que guardaba en su interior fueran liberándose poco a poco de su prolongado encierro» (256). 
siempre existe una necesidad recíproca entre lo apolíneo y lo dionisíaco, que es imposible negar del todo ese aspecto dionisíaco gracias al cual es posible la forma artística. Entendido eróticamente, la sexualidad, la «maldita sexualidad», no puede ser del todo suprimida.

Todo se origina a partir de una crisis creativa: el insigne escritor no puede avanzar en la obra que tiene entre manos. "¿Se querría vengar ahora su esclavizada sensibilidad?», se pregunta el narrador (467). Se ve impelido a huir. Un deseo extraño anida en su pecho. Durante un paseo, mientras espera el tranvía junto a un cementerio - la muerte se anuncia $a b$ initio-, toda su atención se vuelve sobre un hombre extraño, de apariencia extranjera, que detona un desasosiego interior inusitado, una especie de expansión interna - la palabra alemana es Ausweitung y refiere, en Psyche de Rodhe, al efecto que producen los ritos dionisíacos en el estado mental de los participantes_, «una apetencia de lejanías juvenil e intensa, una sensación tan viva, nueva o, al menos, tan desatendida y olvidada hacía tanto tiempo» (465). «Eran ganas de viajar, nada más», dice el narrador, "pero sentidas con una vehemencia que las potenciaba hasta el ámbito de lo pasional y alucinatorio». Lo asalta la visión de tierras tropicales, de «una especie de caos primigenio», de «un tigre acechante» (466). Intuye al «Dios extranjero», Dioniso, proveniente de la India, de donde a su vez proviene el cólera que acabará con su vida. Advertimos que esas ganas de viajar, ese «Reiselust, nichts weiter», entraña mucho más de lo que podría sospechar el narrador. Encubre, ya lo hemos sugerido, deseos y sensaciones juveniles, desatendidas y olvidadas, avivadas por este primer mensajero de la muerte.

Decide viajar, «no demasiado lejos; no precisamente hasta el país de los tigres» —no está preparado aún para experimentar el extremo dionisíaco—, sino al «entrañable sur» (468). Interrumpe, pues, la «ferviente y meticulosa dedicación matinal» que inicia su jornada laboral, ${ }^{24}$ precedida por duchas de agua fría — receta manniana para combatir la sexualidad-, y parte «en busca de un exotismo insólito» (476) hacia la tierra de la bellezza.

\footnotetext{
${ }^{24}$ Que es la misma del propio Thomas Mann. Cumple decir que el autor le adjudica a Gustav von Aschenbach las obras que él mismo planeaba escribir y nunca escribió o abandonó inconclusas, entre estas: Federico de Prusia, Maya, Un miserable y El espíritu y el arte. El dato es elocuente: las primeras dos obras abordaban directa o indirectamente el asunto del homoerotismo. En el cuaderno de notas de Mann, leemos sobre sus planes para la primera: «Las tardías tendencias homosexuales de Federico. Hay que mostrar sosegadamente cómo a partir de la edad y de la descomunal superioridad surge una relación erótica con hombres bellos e insignificantes, una relación como la de un hombre con una mujer» (apud Kurzke 2004: 190-191). Comenta Kurzke a partir del material conservado: «Lo que podemos concluir de todo esto es que "Federico" representa a un soberano infeliz en lo privado y que vive apartado de la vida, aquejado de tendencias homoeróticas, que mantiene lo más lejos posible a su mujer y a la familia, a los que ve como despreciables cumplimientos del deber y que, erigiéndose en solitario, se deja halagar por sus bonitos lebreles» (191). Maya, por su parte, estaba concebida como novela social y trataría sobre su relación con Paul Ehrenberg (198).
} 
La idea de que el sur es ardiente y el norte frío no es original de Thomas Mann. Así lo refiere Voltaire en Candide:

Les peuples septentrionaux n'ont pas le sang assez ardent [...] Il semble que vos Européans aient du lait dans les veines ; $c^{\prime}$ est du vitriol, c'est du feu qui coule dans celles des habitants du mont Atlas et des pays voisins. ${ }^{25}$

El cliché, aunque no necesariamente cierto, nos acompaña incluso en nuestros días. La reflexión manniana, sin embargo, va mucho más allá del cliché popular y se enmarca en una tradición que cumple recordar: la seducción del Mediterráneo. ${ }^{26}$ Por siglos, las tierras cálidas del sur se han vinculado al despertar sexual, en especial homoerótico. Richard Burton, en su «Terminal Essay» (1885) a la monumental traducción de Las mil y una noches, exponía la tesis de que el clima cálido y la geografía propician la orientación homosexual, en especial en la llamada zona sotádica, esto es, el sur de España y de Francia, Italia, Grecia, Asia Menor, América, entre otros, siendo la capital Venecia en cuanto puente entre Oriente y Occidente. En 1594, Thomas Nashe bautizó a Venecia como «the Sodom of Italy» en The Unfortunate Traveller, idea retomada por Lord Byron en Marino Faliero (1821) al referirse a Venecia como «the sea-Sodom of Italy». ${ }^{27}$ August von Platen, primera voz alemana abiertamente homosexual, dedicó varios sonetos a Venecia en los que el deseo homoerótico se mezcla con la descripción del paisaje veneciano. Importa decir que este autor late intensamente tras Gustav von Aschenbach: Gustav, además de evocar a Gustav Mahler (que murió justamente cuando Thomas Mann estaba en Venecia y sirvió de inspiración para el retrato físico de nuestro protagonista), podría leerse como un anagrama de August, mientras que Aschenbach podría remitirnos a la ciudad natal del poeta, Ansbach. El vate, al igual que el distinguido von Aschenbach, murió de cólera en Italia. Thomas Mann dedicó un importante ensayo a August von Platen (1930) que nos ayudará a establecer la relación Eros-Tánatos que subyace en Muerte en Venecia. Antes, cumple citar el poema Tristan, del cual parte la relación entre belleza, Eros y muerte:

Wer die Schönheit angeschaut mit Augen,

Ist dem Tode schon anheimgegeben,

Wird für keinen Dienst auf Erden taugen,

Und doch wird er vor dem Tode beben.

Wer die Schönheit angeschaut mit Augen!

Ewig währt für ihn der Schmerz der Liebe,

Denn ein Tor nur kann auf Erden hoffen,

\footnotetext{
25 He citado por la edición de acceso abierto de Project Gutenberg: $<$ https://www.gutenberg.org/cache/epub/4650/pg4650-images.html>.

${ }_{26}$ Véase al respecto Aldrich (1993).

${ }^{27}$ Los ejemplos provienen de la introducción de Galloway y Sabisch a su antología (1982: 46$48)$.
} 
Zu genügen einem solchen Triebe:

Wen der Pfeil des Schönen je getroffen,

Ewig währt für ihn der Schmerz der Liebe!

Ach, er möchte wie ein Quell versiechen, Jedem Hauch der Luft ein Gift entsaugen Und den Tod aus jeder Blume riechen:

Wer die Schönheit angeschaut mit Augen,

Ach, er möchte wie ein Quell versiechen! 28 (Platen 1999: 72)

«Quien haya contemplado con sus ojos la Belleza, está ya consagrado a la muerte... ¡Para él durará para siempre la pena de amor! Pues solo un loco puede esperar, sobre la tierra, ver satisfecho un impulso como este». Thomas Mann, a propósito del poema, contradice respetuosamente a Goethe cuando declaraba que Platen «carecía de amor» y reconoce libremente la circunstancia fundamental en la vida y obra de Platen: la circunstancia decisiva de su inclinación «exclusivamente homosexual» (1975: 188). Arguye:

El amor impregna el poema en cuestión y toda su obra melancólica y exaltada, continuamente entusiasta e inclinada a altos vuelos, ese amor infinito, insaciable, que desemboca en la muerte, que es la muerte porque no encuentra nada que le satisfaga en la tierra, ese amor que le hiere temprano, sin remisión, y que él llama «la flecha de la belleza». (Mann 1975: 184)

Este mundo de la belleza, un mundo en el que las leyes vitales, la razón y la moral no tienen ya validez alguna, se corresponde, en gran medida, al deseo homoerótico, a un amor infinito, sí, pero insaciable y prohibido, que desemboca en la muerte precisamente por la imposibilidad de su satisfacción. ${ }^{29}$ La flecha de la belleza, representada por Tadzio, «es la de la muerte y la del eterno mal nostálgico» (185), «infinita y dolorosa nostalgia» (187), «una tensión eterna sin solución posible» (carta, apud Kurzke 2004: 404), es deseo y perdición, un «donquijotismo apasionado, siempre perdedor» (1975: 191). Perdedor pero a la misma vez ennoblecedor — pese a la pérdida de la dignidad a la que se ve abocado Aschenbach—, pues «el dios habita en el amante y no en el amado», leemos tanto en Muerte en Venecia (508) como en el ensayo sobre Platen (190).

28 «Quien con sus propios ojos ha visto la Belleza, / se ha entregado en los brazos de la muerte; / para ningún servicio es apto ya en el mundo; / y temblará no obstante ante la muerte, / quien con sus propios ojos ha visto la Belleza. // Entre penas de amor permanecerá siempre, / pues solo un loco puede esperar que en el mundo, / se llegue a disfrutar de impulso semejante: / Aquel al que alcanzó Belleza con su dardo, / entre penas de amor permanecerá siempre. // Ah, deseará secarse como los manantiales, / en cada soplo de aire aspirar un veneno, / y oler la muerte en cada flor: Aquel / que con sus propios ojos contempló la Belleza, / ah, deseará secarse como los manantiales». La traducción es de David Pujante (Platen 1999: 72-73).

${ }_{29}^{29}$ Thomas Mann insiste en la relación entre homoerotismo y esteticismo en su ensayo Sobre el matrimonio, donde equipara a ambos con la muerte, en contraposición al matrimonio, que equivale a vida, a orden y a moral burguesa. 
Mann cita a Nietzsche: «El grado y tipología de la sexualidad de un individuo alcanzan hasta las cimas más elevadas de su espiritualidad» (189).

Venecia, así pues, es el destino que aguarda a Gustav von Aschenbach.

Venecia, ciudad extraña, ambigua, en la que convergen oriente y occidente, participa de dos naturalezas, es terrestre y es acuática, es civilizada, con un refinamiento decadente, y es a la vez heredera de una tradición clásica y patricia. (Glantz 1976: 5)

Ciudad sobre aguas estancadas y pútridas, que nos hace recordar las aguas en las que perece el pequeño señor Friedemann, se abre hacia la inmensidad del mar, símbolo de eternidad y de muerte. Muerte anunciada por el forastero pelirrojo con traje amarillento frente al cementerio, que descansa sobre un bastón apoyado en su cadera, con los pies cruzados, con sus dos enérgicas arrugas, la manzana de Adán pelada y prominente, y cuyos cortos labios dejan al descubierto su larga dentadura; por el grumete con barbas de chivo y dedos huesudos y amarillentos de la cabina; por el «falso joven», vestido con traje amarillo y corbata roja, de dentadura amarillenta, que viajaba en el mismo barco; por el gondolero de origen no italiano, de cejas rojizas y con chal amarillo, que al remar contrae los labios dejando al descubierto los dientes; por el músico callejero, de rostro enjuto y amojamado, surcado por dos arrugas obstinadas y amenazantes, pelirrojo, con la manzana de Adán prominente y pelada bajo su maliciosa sonrisa, de origen no veneciano y reflejo del artista indigno; y por el propio Tadzio, con su inconfundible lazo rojo sobre el pecho, sus dientes desgastados, siempre apareciendo por la izquierda - ya Lessing había escrito que la muerte se presenta por la izquierda - y con la usual pose que asume al apoyar su antebrazo en la balaustrada, los pies cruzados y la mano sobre la cadera. El «espacio vacío e inarticulado» del mar supone un viaje a lo informe, a la eternidad y, por tanto, a la muerte:

Amaba el mar por razones profundas: por la apetencia de reposo propia del artista sometido a un arduo trabajo [...] y también por una propensión ilícita hacia lo inarticulado, inconmensurable y eterno: hacia la nada. ${ }^{30}(493)$

Los gestos odiosamente ambiguos y escandalosos que hace el viejo petimetre con la lengua evocan sexualidad desenfrenada, la cual aguarda al contenido Aschenbach en su sueño orgiástico, al igual que la barba de chivo (de sátiro, acompañante de Dioniso), preparan el terreno para lo insólito y deforme. El asiento mullido de la góndola, cuna y sarcófago — según leemos en uno de los Epigramas venecianos de Goethe-, y barca de Caronte, concentra en sí el véneto hechizo de indolencia y abandono.

\footnotetext{
${ }^{30}$ Muerte también en un sentido schopenhaueriano, pues implica la disolución de lo diverso e individual en la infinitud indiferenciada. En Lübeck como forma de vida espiritual: «El mar no es un paisaje, es la experiencia de la eternidad, de la Nada y de la Muerte» (Mann 2016a: 49).
} 
La visión del bellísimo efebo Tadzio, ideal de belleza visto desde una perspectiva apolínea, la «purísima perfección en sus formas» (487), y de su mirada gris y crepuscular, evocadora de la muerte, detonan en Aschenbach el pensamiento de que, si bien sus ideas artísticas se asemejan a las imágenes reveladoras de los sueños - en la filosofía de Nietzsche, Apolo es el dios de la forma, de los sueños y de lo escultórico-, en estado de vigilia se tornan totalmente triviales e inservibles. Otra vez, la inadecuación del arte en la vida. El artista sospecha que el arte es mucho más que la forma perfecta, en extremo apolínea, que ha cultivado desde sus años juveniles. Poco a poco, «esa preciosa obra de arte de la naturaleza» empieza a despertar a Eros: notaba en aquella figura de adolescente «un relieve que permitía tomarlo en serio pese a sus escasos años» (494). La visión «de ese efebo con los rizos empapados y bello como un dios, que emergía de las profundidades del mar y del cielo, luchando por desprenderse del líquido elemento» (495) evoca el nacimiento de Venus, otra vez Eros. Aschenbach comprueba que la ciudad le resulta «altamente perjudicial» (497), acaso por su aire denso y caliente, por el «estado de excitación y abatimientos simultáneos» que le produce. Algo le oprime el pecho, le entra fiebre, siente la sangre latirle en la cabeza: comprende que tiene que marcharse. Lo intenta, huye, pero no puede: el destino es inexorable. Y él lo sabe. Por eso lo abraza mediante «un gesto de complaciente bienvenida, de solícita y serena aceptación» (503). La noble figura del efebo, perfecta escultura divina (Apolo), remite a la idea de belleza perfecta y supone una suerte de anamnesis platónica, pero al mismo tiempo produce un arrebato de entusiasmo y embriaguez (Rausch) dionisíaca: «Y, sin advertirlo, o más bien con fruición, el senescente artista le dio la bienvenida» (507). «Su embriaguez le resultaba demasiado grata» (510). «Con una sonrisa entre confusa y admirada reconocía entonces antiguos sentimientos, penas del corazón tempranas y entrañables que, asfixiadas por el severo oficio de toda una vida, retornaban ahora, extrañamente transformadas» (512). (¿Se referirá acaso a la nostalgia erótica que viviera el joven Tonio Kröger?) El retorno de esos poderes embriagadoramente destructivos y aniquiladores es dulce y amargo, supone una desestabilización indignante y abyecta, al mismo tiempo que sagrada. La persecución furtiva y silente, sin tregua, se ve correspondida con una sonrisa fatal. «Te amo», musita estremecido (515).

¿Qué hubieran dicho? [...] ¿Qué hubieran dicho de su vida toda, que se había ido apartando de la de ellos hasta la degeneración; de esa vida ofrendada al arte, de esa vida que él mismo, fiel al espíritu burgués de sus padres, había, en otro tiempo, hecho objeto de sus sarcasmos juveniles? [...] Una vida basada en el autodominio y en la obstinación, una vida ardua, hecha de perseverancia y abstenciones, transformada por él en símbolo de un heroísmo refinado y tempestivo, bien podía ser calificada de viril y valerosa; y el Eros que se había posesionado de él le empezó a parecer, en cierto modo, particularmente idóneo y afecto a semejante género de vida. ¿No había ese amor gozado de la más alta estima entre pueblos de gran valentía? ¿No se decía incluso que el valor lo había hecho florecer en sus ciudades? Numerosos héroes de la Antigüedad habían soportado, gustosos, su yugo, pues 
ninguna humillación era tal si la infligía el dios [...] Así manipulaba el obcecado sus ideas, así intentaba reforzarlas y salvaguardar su dignidad. (520-521)

Esta apología de Eros por parte del protagonista es, en realidad, una apología del homoerotismo. Las abstenciones, la renuncia, solo se explican por su naturaleza prohibida y transgresora. ¿Pero no era estimado este amor entre los grandes pueblos del pasado, aquel pueblo griego que serviría de ejemplo y modelo artístico y vital durante siglos? Luego de la apología, como es de esperar, prosigue la ironía. El narrador se distancia de las ideas del senescente, del ciego enamorado que está a punto de perder enteramente su dignidad. La ironía manniana siempre supone distanciamiento, un constante movimiento dialéctico que oscila entre dos polos enfrentados, y no necesariamente está ligada a lo cómico, sino a una profunda tensión ambigua que funciona a modo de coraza. Lo reconoce Eugenio Trías:

Un sentimiento determinante de pudor, de autovergüenza, le impedía otro desbordamiento aquel que le permitiera el marco distanciador de la ironía veneradora. Ironía veneradora, nunca rebajadora ni reductora [...] Interpretar a Mann significa ironizar respecto a los móviles de su propia ironía. Solo así se puede comenzar a comprender y querer a quien fue víctima propiciatoria de su propio sentido de la dignidad y el ridículo. (Trías 2017: 37)

\section{En lo mismo tercia Kurzke:}

El pathos sería sentimiento, apertura, abandono. La ironía, en cambio, es camuflaje. Ironía significa no dejarse atrapar en una pasión, en un sentimiento, significa seguir siendo superior y mostrarse inatacable. «La ironía casi siempre significa convertir un apuro en superioridad». (Kurzke 2004: 141)

Ironía «simpatizante» la llama Roman Karst (1974: 51).

Luego de advertir el caos, tanto el epidémico ${ }^{31}$-tanático como el erótico, le sobreviene un sueño terrible, una visión dionisíaca, que resulta de esos acontecimientos que,

al irrumpir desde fuera, fueron derribando violentamente su resistencia —una resistencia surgida de las profundidades de su espíritu- y dejaron tras sí, asolado y deshecho, el edificio entero de su existencia y la cultura de su vida. (531)

Gracias a Freud sabemos que los elementos reprimidos nunca pueden ser aniquilados, sino que tienden incesantemente a reaparecer en la consciencia por

${ }^{31}$ La palabra «epidemia» proviene del verbo griego ė $\pi ı \emptyset \eta \mu \varepsilon ́ \omega$, que significa 'estar en casa, en la ciudad, en la patria o volver a ella' y también 'habitar en calidad de forastero'. El dato no es trivial: la estancia de Aschenbach en Venecia, en tiempos de epidemia, supone un retorno a casa, tanto en el sentido de reecontrarse con la sangre materna como un regreso al origen de todo: al fondo dionisíaco a partir del cual se produce el embellecimiento apolíneo que deriva en arte y al fondo erótico latente transfigurado en la obra de toda una vida. También supone la estancia de las figuras foráneas que pueblan la Novelle, representantes del «dios extranjero» y, en el fondo, del propio viajero Aschenbach. 
caminos misteriosos y mediante formaciones derivadas del inconsciente. «Das Verdrängten ruht wie Pompeji unter ein Ascheschicht, jederzeit bereit, wieder ans Tageslicht zu treten» (Dierks 2005: 303), esto es: «Lo reprimido descansa como Pompeya bajo una capa de ceniza, listo para volver a la luz del día en cualquier momento». ${ }^{32}$ (Es oportuno recordar que Aschenbach significa literalmente 'arroyo de cenizas'). Mientras mayor sea la fuerza de contención y cuanto más dure la represión, con mayor fuerza intentará emerger a la consciencia, incluso por las vías más inimaginables. Lo reprimido siempre obtiene finalmente la victoria. Y en sueños, en esos momentos en que duerme la consciencia, aflora. El sueño de Aschenbach, así, más que una visión, es una revelación. El durmiente se enfrenta cara a cara con «el dios extranjero», ErosDioniso, ese que antes se le había presentado a través de sus mensajeros, identificados por el rojo y el amarillo, las barbas de chivo, la lengua ambigua e indecorosa, las dos arrugas amenazantes, los dientes, la manzana de Adán, los pies cruzados, la mano en la cadera, etcétera. Además de mensajeros de la muerte, eran filtraciones de lo reprimido hacia la consciencia. ${ }^{33}$ Anunciaban la muerte, sí, pues con el pequeño señor Friedemann aprendimos que soltar las cadenas, abrir las puertas del sótano y dejar salir los perros, dar libre curso a todas las pulsiones reprimidas durante toda una vida, conlleva perecer, sucumbir en el abismo hasta perderse. Una vez se produce la revelación, no hay marcha atrás. La irrupción de las ululantes pasiones es total. En el onírico rito orgiástico, no le es posible oponer resistencia al dios porque él ya forma parte de su séquito, de la «cópula promiscua e infinita»: él ya ha sido «poseído también por el dios extranjero» (533). «Su alma conoció la lujuria y el vértigo de la aniquilación».

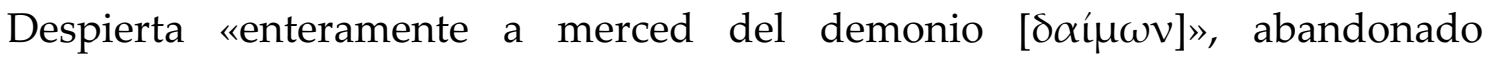
completamente a Eros-Dioniso.

Abandona por fin la máscara. «Ya no temía la mirada inquisitiva de la gente ni le importaba exponerse a sus sospechas». Ya nada importa, solo la satisfacción plena de las pasiones silenciadas y reprimidas durante toda una vida. Abandona la máscara burguesa para adoptar una nueva: una capa de maquillaje, cabello tintado y una corbata roja, reminiscencia del «falso joven» del barco y señal de consagración dionisíaca. Sin tregua persigue al efebo de cabellos de miel, embriagado, arrastrado indignamente por la pasión. Rendido, goteando el maquillaje entremezclado con sudor y sediento, se deja caer sobre los peldaños:

Y allí, sentado, estaba el maestro, el artista que accediera a la dignidad, el autor de Un miserable, que, en forma tan ejemplarmente pura, había adjurado de la bohemia y las

${ }^{32}$ Manfred Dierks (2005) reconoce cómo Thomas Mann aúna el concepto freudiano del retorno de lo reprimido (Wiederkehr des Verdrängten) con la dicotomía nietzscheana apolíneo-dionisíaco. La cita de Dierks constituye una paráfrasis del estudio de Freud sobre Gradiva.

${ }^{33}$ Lo sugiere indirectamente Robertson cuando afirma: «They represent the unacknowledged and unwelcome shadow-side of Aschenbach himself, the rootless, bohemian aspect which he has done his best to repress. [...] His repressed emotions appear just where he thought he was safest: amid his devotion to classicism» (2001: 101). 
profundidades turbias, denegado su simpatía al abismo y abominado lo abominable; el escritor encumbrado que, superando su propio saber y emancipándose de toda ironía, se había situado a los compromisos impuestos por la confianza de las masas; el artista de fama oficial, cuyo nombre había sido ennoblecido y cuyo estilo servía de modelo a los adolescentes: allí estaba sentado, entornando los párpados... (537)

Retorna lo reprimido, al decir de Freud, en forma de transacción.

Al final, el «adorable psicagogo», «rodeado de mar y viento, ondeante la rizosa cabellera, como una aparición aislada y desligada de todo, flotando ante la bruma gris del infinito [...], apoyada una mano en la cadera, [...] le sonreía a lo lejos», según la impresión del moribundo, «le hacía señas, como si, separando su mano de la cadera, le señalase un camino y lo empezara a guiar, etéreo, hacia una inmensidad cargada de promesas. Y, como tantas otras veces, se dispuso a seguirlo. (540-541).

\section{De Hans CASTORP a FÉLIX KRULl}

Hemos cerrado el arco que se tiende desde El pequeño señor Friedemann hasta Muerte en Venecia, unido, según Thomas Mann, por el constante motivo fundamental que da cohesión a toda su obra: el retorno de lo reprimido. Es cierto que esta "papilla primigenia» se va agotando y va dejando de ser central, mas nunca desaparecerá del todo. Thomas Mann ya no sería el mismo. Pero, aunque las circunstancias cambien, un gran escritor nunca se cansa de reescribir sus obsesiones íntimas. No quisiera terminar estas reflexiones sin referir muy brevemente algunas vivencias de Hans Castorp, Adrian Leverkühn y Félix Krull.

En La montaña mágica (1924), volvemos a encontrar al joven que disfruta el retiro del mundo y se crece gracias a ello, gracias a la llamada Innerlichkeit, interioridad o vida interior. El Lied de Mahler, citado hacia el inicio de estas páginas, aparece citado indirectamente varias veces en la novela. A Hans Castorp se le llama «das Abhandengekommene» en «Asalto rechazado» (VI). En «Mynheer Peeperkorn (continuación)» dice el joven:

Ich schreibe nie Briefe. An wen wohl? [...] An wen sollte ich wohl Briefe schreiben? Ich habe niemanden. Ich habe gar keine Fühlung mehr mit dem Flachland, die ist mir abhanden gekommen. Wir haben ein Lied in unserem Volksliederbuch, worin es heißt: «Ich bin der Welt abhanden gekommen». So steht es mit mir. (VII, 747)

Esto es:

Nunca escribo cartas. ¿A quién iba a escribir? [...] No tengo a nadie. Ya no tengo relación alguna con el mundo de allá abajo. He perdido todo contacto. En nuestro cancionero popular hay un verso que dice: «Estoy perdido para el mundo...». Ese es mi caso. (VII, 872)

En el apartado siguiente, lo reitera y parafrasea otro verso del Lied: «so daß ich nun dem Flachland völlig abhanden gekommen und in seinen Augen so gut wie tot 
bin» (VII, 769), «de ese modo me perdí para el mundo y podría decirse que es como si hubiese muerto» (VII, 896).

También encontramos en esta novela otro vínculo homoerótico entre jóvenes: Hans Castorp y Pribislav Hippe, así como en la transposición de la experiencia erótica juvenil a Clavdia Chauchat. Thomas Mann recrea una vivencia que tuviera en su temprana juventud: su fascinación erótica por el compañero de clase Williram Timpe, a quien el joven Thomas pidió prestado ese lápiz que le pide Hans Castorp primero a Hippe y luego a Madame Chauchat. ${ }^{34}$ Durante un paseo alegre, en el que Hans Castorp cantaba a pleno pulmón, de pronto comenzó a sangrarle la nariz. Tumbado en un banco le sobrevino una visión, «singularmente embriagadora» («Hippe», IV, 173). Se vio remontado al colegio, donde vio a Pribislav Hippe, rubio, de ojos tártaros, grises azulados o azules grisáceos, que despertaba en él un deseo singular. Ni siquiera lo conocía, pero durante todo un año lo había seguido siempre con la mirada y sentía «algo tan íntimo» (175) que los unía y que no sabía cómo nombrar. Esa relación «muda y desde la distancia» (176) —como la de Aschenbach y Tadzio— se convirtió en «uno de los pilares inamovibles de su vida»:

Amaba la excitación que le causaba, la tensión de si se encontrarían ese día, si el otro pasaría cerca de él, si tal vez le miraría... amaba las calladas y tiernas pequeñas satisfacciones que le producía su secreto, e incluso las decepciones obligadas, la más grande de las cuales era que Pribislav «faltase». (176)

En un arranque de determinación, ansioso de cercanía, de entablar, aunque fuera un contacto único que rompiera el silencio de aquella secreta y larga relación, aprovechó la ocasión de pedirle prestado un lápiz para su clase de dibujo. Estaba cegado, mientras una convulsión hervía en su interior, cuando preguntó: «Perdona, ¿puedes prestarme un lápiz?» (177). «Con mucho gusto — dijo—. Pero me lo tienes que devolver sin falta después de la clase», respondió con «voz agradablemente ronca»y le explicó el mecanismo para que saliese la punta roja. «Eso fue todo», dice el narrador. No es poco. Las implicaciones del sutil erotismo de la escena, cifrado en el símbolo fálico del lápiz, se remarcarán a lo largo de toda la novela. Ese encuentro íntimo — pues para el joven Hans lo es— quedaría

\footnotetext{
34 «Que Thomas Mann convierta a Hippe en un chico de trece años, es decir, que remonte la vivencia de la cima de la pubertad a lo prepubertario y, de este modo, lo despoje hasta cierto punto de su sexualidad, tiene sentido en la novela en la medida en que en ella la sexualidad materializada le es atribuida a una mujer, Clawdia Chauchat, a la que Hippe reproduce tipológicamente. Visto así, el préstamo del lápiz es una temprana premonición de lo que sexualmente no llega a culminar más que en la relación con una mujer. Que en la novela la vivencia del lápiz no le suceda a un muchacho de dieciséis o de diecisiete años, sino a uno de trece, pretende protegerla de la suposición de que hubiera habido una relación sexual entre Hans y Hippe. Thomas Mann no llevó una doble vida. No se acercaba sigilosamente a muchachos jóvenes a fin de hacer con ellos algo prohibido. Era demasiado temeroso para eso» (Kurzke 2004: 50). Aunque el lápiz no representa una relación sexual consumada, sí concentra la profunda tensión erótica que nunca acaba de resolverse del todo.
} 
grabado a fuego para siempre en su memoria. Y sería el resurgimiento de este recuerdo lo que lo atrape del todo en el «mundo de allá arriba», transferido a la figura de Clavdia Chauchat. Es ella quien lo despierta por su increíble parecido: tienen los mismos ojos de kirguís, ${ }^{35}$ el cabello rubio, la misma voz ronca o velada, la misma risa, la misma manera de sentarse, la mano de ella no es femenina y parece de colegiala... «¡Cómo se parecía a esa mujer del sanatorio! ¡A la de aquí arriba! ¿Por eso me interesa tanto ella? O es al revés: ¿Por eso me interesó tanto él en tiempos?» (178). Las lágrimas que inundan sus ojos nos dicen la respuesta. Pero si no ha quedado clara, un psicoanalista, el Dr. Krokovski, nos lo explica en su conferencia titulada «El amor como factor patógeno», a la que Hans Castorp asiste inmediatamente después de su visión. Vale la pena citar el pasaje en extenso:

Esa lucha entre las fuerzas de la castidad y el amor — pues de una lucha se trataba—, ¿cómo terminaba? Aparentemente con la victoria de la castidad. El temor, el decoro, el asco escrupuloso y el trémulo deseo de pureza han reprimido el amor y lo han mantenido encadenado a las tinieblas, concediendo que - a lo sumo- se realizasen y se tomase conciencia de sus desordenados impulsos en parte, pero desde luego, no con toda su fuerza en su ingente pluralidad. Por ende, esa victoria de la castidad solo es aparente, una victoria pírrica, dado que el impulso amoroso no se puede domeñar, no se puede violentar; el amor reprimido no muere; vive y, aun en la más secreta oscuridad, aspira a realizarse; rompe la mordaza de la castidad y vuelve a salir a la superficie, si bien en una forma diferente, irreconocible... («Análisis», IV, 184).

En ninguna otra obra de Thomas Mann encontramos una exposición tan clara y completa sobre el retorno de lo reprimido, una reflexión sobre el erotismo en la que podrían verse reflejados muchos de los personajes mannianos, tanto como su creador. La victoria que supone la castidad autoimpuesta - sea por motivos conscientes o inconscientes, sea voluntaria o involuntaria-, consistente en encadenar el amor a las tinieblas, es decir, encadenar los perros en el sótano, no es sino una victoria aparente, pues, como bien descubre Aschenbach, las pulsiones eróticas no se pueden aniquilar del todo, no se pueden domeñar durante toda la vida, pues el amor reprimido nunca muere; siempre aspira a realizarse, siempre busca la satisfacción incluso en la oscuridad y en el secreto más íntimo, siempre busca válvulas de escape, vías insospechadas que rompan la mordaza de la castidad y le permitan salir a la superficie, aunque sea en una

${ }_{35}$ Ciertamente este rasgo tiene implicaciones que trascienden el aspecto puramente erótico y corresponden a una reflexión más profunda sobre Rusia y lo oriental-asiático, pero ello no quita sus implicaciones eróticas, tan presentes en la obra. Kurzke comenta que «el ruso es una palabra en clave que representa toda clase de tentaciones» (2004: 354). Cumple recordar que el matrimonio ruso que se aloja en la habitación vecina a la de Hans Castorp, cuyos movimientos nocturnos $-\mathrm{y}$ aun diurnos - el joven escucha ruborizado y sobresaltado, se caracteriza por su sexualidad libre e intensa, la cual, por indiscreta y ruidosa, contraviene las normas burguesas y, por ello, causa el disgusto de los huéspedes, que los bautizan como «los rusos vulgares». No debe sorprendernos, pues, que Madame Chauchat, también rusa, propicie el resurgir de la sexualidad problemática de Hans Castorp. 
forma metamorfoseada. Esa forma puede ser la figura femenina - aunque no tan femenina- de Madame Chauchat. La asociación entre ambas figuras es reiterada: «Pues, cuando un hombre se interesaba por una mujer enferma, no era la razón la que entraba en juego, sino... algo similar a lo que, en tiempos, había sentido en silencio por Pribislav Hippe» (187). La confusión identitaria, que hallará su culmen cuando se produzca el intercambio del lápiz entre ambos, persiste a modo de ostinato:

«Se parecían» no terminaba de ser la expresión apropiada; más bien eran los «mismos» ojos, como también la anchura de la mitad superior del rostro, aquella nariz un poco chata..., todo, $[. .$.$] todo era igual que en Pribislav, y así le había mirado este cuando se$ cruzaban en el patio de la escuela. («Angustia en aumento», IV, 211)

Lo que atrae a Hans Castorp de Clavdia Chauchat, además de su exotismo y de su vulgaridad, de sus modales inimaginables $\rightarrow$ su falta de maneras burguesas es símbolo de libertad y transgresión-, es la huella del amor homoerótico de juventud, desplazado a ella. A través de ella, logra revivir esas sensaciones olvidadas, logra sacar a la luz ese amor reprimido imperecedero, que en el mundo de allá arriba, donde rigen otra moral y otras normas distintas a las burguesas, a las del llano, es lícito vivir. Pero poco a poco, pues

la sensatez y la integridad con que Joachim se resistía y huía de la influencia de aquel ambiente impresionaban a Hans Castorp, le imponían también a él cierto orden y cierta disciplina, impidiéndole - por así decirlo- «pedir prestado el lápiz» a la mujer de los ojos achinados. («iDios mío, lo veo!», V, 298)

La ocasión se da en la noche de Walpurgis, noche de Carnaval, esto es, cuando todo está permitido. Algunas mujeres van vestidas de hombre y algunos hombres de mujer: el travestismo festivo propicia desde el inicio la ambivalencia sexual y la disolución de los límites y de lo diferenciado. Hans Castorp, que ha bebido bastante, desea participar en uno de los juegos, que consiste en dibujar a ciegas un cerdito, pero no tiene lápiz. (No olvidemos que el lápiz que pide prestado a Hippe era para la clase de dibujo). Divisa a Clavdia, que llevaba un sensual vestido que dejaba sus brazos al desnudo, y le dice: «¿No tendrás un lápiz por casualidad?» («Noche de Walpurgis», V, 482). Las copas de más y la libertad carnavalesca lo llevan a tutearla, tal como había tuteado en su juventud a Pribislav. «Estaba pálido como la muerte», dice el narrador, «tan pálido como aquella mañana en que, manchado de sangre, regresó de su paseo en solitario y entró a la conferencia del doctor Krokovski». Otra clave: el narrador rememora la conferencia que trataba precisamente sobre el retorno de lo reprimido. Madame Chauchat le presta el lápiz, «un minúsculo lapicero de plata, delgado y frágil, un pequeño artículo de fantasía que apenas podía servir para escribir en serio. Aquel otro lápiz de antaño, el primero, había sido más útil y resistente» (483). Le ofrece un lápiz frágil y delicado, quebradizo, menos útil y valioso que 
el que le ofreciera Pribislav, tan frágil y quebradizo acaso como el erotismo representado por esta sombra reminiscente.

Avanzada la noche, siguen conversando, aunque en francés, que equivale, para Hans Castorp, a hablar sin responsabilidad, a hablar como en sueño. Amparado en esta lengua le es posible decir todo lo que desea, sin inhibiciones. Le habla de Pribislav Hippe, le dice que ya la amaba desde aquel amor irracional que sentía por el joven; es decir, se confunden las identidades de Clavdia y Pribislav en una. Puede confesar su amor por él, dejarlo salir a la superficie, a través de ella, gracias a su sexo femenino — que no a su femineidad—, gracias a la libertad que reina en el mundo de allá arriba y gracias a la noche de carnaval. Le declara su amor en términos puramente anatómicos y luego no sabemos si ocurre algo más. ${ }^{36}$ "N'oubliez pas de me rendre mon crayon», dice ella y se marcha (497). El intercambio del lápiz es el acto —aunque simbólico- más extremo que puede darse de momento. Y puede que no sea poco: es de las pocas veces que en la obra manniana se superan las inhibiciones y no se acaba mal parado. El 12 de marzo de 1920 escribía Thomas Mann en su diario: «La montaña mágica va a ser lo más sensual que haya escrito nunca, pero en un estilo frío» (apud Kurzke 2004: 355). Robert Musil se burlaría de ello al leer la escena: «Ese Castorp tiene el miembro de yeso» (Kurzke 2004: 355). Sin embargo, luego de nuestro recorrido podemos decir que el gran hombre tenía razón.

En «Nieve», esa experiencia central de la novela en la que Hans Castorp se enfrenta con el Todo y con la Nada, resurge varias veces el recuerdo de Pribislav Hippe y Clavdia Chauchat. El narrador insiste en la «embriaguez» del personaje, incluso desde antes de que se beba el oporto. La tormenta de nieve en la que se pierde a riesgo de perecer lo incita a pensar una y otra vez en la escena del lápiz: «Con mucho gusto — se dijo a media voz rompiendo el silencio que le rodeaba-. Pero no lo rompas» (VI, 696). Luego retorna el pensamiento del carnaval, el cual le evoca una situación igual de «demencial y terrible» que en la que se encuentra: «devolverle a la enferma Clavdia Chauchat el lápiz... el lápiz de Pribislav Hippe...» (712). Otra vez, las identidades se confunden. El francés, esa lengua de

${ }_{36}$ Para Kurzke (2004: 355), sí viven una única noche de amor, sugerida por medio de enigmáticas alusiones, como que más tarde devolvió el lápiz y recibió otra cosa a cambio. Sin embargo, el narrador rápido aclara que se trata de «un recuerdo que ahora llevaba siempre en el bolsillo», el retrato interior de Clavdia, esto es, su radiografía («Cambios», VI, 502-505). Aunque los equívocos, tanto de la alusión misma como de los símbolos empleados, da pie a pensar que sí sucede, no podemos descartar la posibilidad de que no suceda nada más allá del beso ruso que presenciamos tras su retorno. La profunda ambigüedad, sostenida en adelante, es reconocida por el propio narrador, cuando tras narrar el beso, pronuncia: «¿Somos ambiguos nosotros al hablar ahora del beso ruso, o lo son Hans Castorp y Clavdia al dárselo? [...] ¿Ambigüedad? ¡Dejemos que sea ambiguo el significado del amor, por Dios! Esa ambigüedad es vida y es humanidad» («Mynheer Peeperkorn (continuación), VII, 880). Cuando Mynheer Peeperkorn le pregunta a Hans Castorp si había sido amante de Clavdia, las respuestas también son ambiguas: «Exageraría si confirmase su suposición y mentiría si la negase por completo» (891). Luego añade: «No he dicho que me haya correspondido alguna vez. Lo creo poco probable» (893). 
ensueño que anula las inhibiciones, contribuye a la confusión: «¿Cómo voy a devolverle a Clavdia Chauchat el lápiz de Pribislav Hippe? En francés se dice "son crayon" porque "crayon" es masculino, y da igual si el poseedor también lo es o no, pero entonces no se sabe si es "suyo de él" o "suyo de ella", aunque tampoco se le puede devolver "a ella" lo que es "de él" ... ¡Pero qué galimatías!». (En alemán, el posesivo distingue el género del poseedor: «sein» para el masculino, «ihr» para el femenino). ¡Vaya momento oportuno para tales disquisiciones, cuando la vida misma está en peligro de muerte a causa de una inclemente tormenta de nieve! Hans Castorp intuye que Claudia y Pribislav son el mismo. La lógica onírica coadyuva al retorno de lo que atesora el inconsciente, retorno metamorfoseado del amor de pubertad. Emergen las pulsiones homoeróticas, cifradas en el lápiz, a través de ella. Inmediatamente después le sobreviene una visión en extremo curiosa: ve la inmensidad del mar, pero no cualquier mar, sino «un mar del sur» (714). Ya sabemos las implicaciones que el sur conlleva en la obra manniana, en esencia eróticas, si bien «Hans Castorp no había visto jamás aquel paisaje ni nada semejante [...] nunca había llegado hasta el Mediterráneo [...] Sin embargo, se acordaba [...] como si desde siempre hubiese llevado en su corazón aquella imagen de la felicidad, del sol y del azul - en secreto, negándosela incluso a sí mismo»(715). Ve «hombres inteligentes y alegres, bellos y jóvenes... un placer para la vista... El corazón de Hans Castorp se abrió como no lo había hecho nunca, tan profundamente y tan lleno de amor que casi le dolía» (716). No tenemos espacio para referir ni desentrañar esta compleja visión ni tampoco para aquilatar su trascendencia, ${ }^{37}$ pero baste con decir que Hans Castorp contempla lo apolíneo y lo dionisíaco, y anhela elevarse por encima de esos contrarios que tan violentamente escinden a los personajes mannianos. También importa destacar la presencia unitaria de Hippe-Chauchat en la experiencia, retomada al final:

He aprendido mucho entre las gentes de aquí arriba, mucho sobre la razón y la sinrazón. [...] Sé todo cuanto atañe al hombre. He llegado a conocer su carne y su sangre, he devuelto a la enferma Clavdia Chauchat el lápiz de Pribislav Hippe. (721)

Es cierto que Thomas Mann elabora aquí reflexiones mucho más profundas y que trascienden el individuo o el hecho personal erótico, pero resulta significativo y elocuente que los símbolos empleados nazcan precisamente de la «papilla primigenia».

Pero no hemos terminado de escuchar al doctor Krokovski. El Eros reprimido siempre aspira a realizarse, rompe el anatema de la castidad y sale a la superficie de una forma diferente e irreconocible. Esa forma, esa máscara bajo la cual reaparece es... - las mujeres apenas respiraban en espera de respuesta«Bajo la forma de la enfermedad. - El síntoma de la enfermedad era el reflejo de una actividad amorosa reprimida, toda enfermedad una metamorfosis del amor»

\footnotetext{
${ }^{37}$ Para ello, remito a Tollinchi (1973) y a García Ponce (1967).
} 
(IV, 185). Y vale preguntarnos: ¿qué enfermedad retiene a Hans Castorp en el Berghof? ¿Una afección pulmonar? ¿Un falso diagnóstico? ¿La seducción por el indolente estilo de vida de allá arriba? ¿Un deseo de retirarse del mundo de allá abajo? ¿La necesidad de retomar, revivir o realizar su experiencia erótica, como queda sugerido en el diálogo en francés durante la noche de Walpurgis? La enfermedad de Hans Castorp no es otra que la metamorfosis de su amor reprimido, siempre latente, el cual se manifiesta, a su vez, en su simpatía por la muerte. Eros y Tánatos, nos enseñaba la dicotomía Kröger-Aschenbach (y, a su vez, August von Platen), coexisten y están atados por una misma cuerda de igual modo que Apolo-Dioniso. Ambos suponen la disolución de la individualidad en la unidad infinita. La simpatía por la muerte, omnipresente en toda la novela y representada también por múltiples figuras, queda cifrada en el Lied que tanto fascina a Hans Castorp: Der Lindenbaum del ciclo Winterreise de Franz Schubert. Y hallará en la guerra su máxima realización, cuando Hans Castorp, al perderse en ella, se desprenda de su individualidad para unirse al todo indiferenciado, o a la nada. Será la vía que lo aguarda para satisfacer por fin el erotismo latente. ${ }^{38}$

Ya hemos citado la renuncia a Eros que se produce en el Doktor Faustus (1947) como condición del pacto mefistofélico que sella Adrian Leverkühn: le está vedado todo tipo de amor humano. Sin embargo, es oportuno mencionar, aunque sea de pasada, la relación entre Adrian y Rudi Schwerdtfeger, con quien el artista descubre por primera vez el calor humano. Adrian le confiesa que es él ese

alguien que, por primera vez en mi vida, me procuró un calor humano [...] alguien, de cuya cordial insistencia podríamos casi decir que fue más fuerte que la muerte. Alguien que despertó en mí lo humano y me reveló la felicidad. (XLI, 604-605)

Y luego oímos en su confesión final:

Creí también [...] amar en cuerpo y alma a quien no era del sexo femenino, pero que había implorado mi tuteo con ahínco tal que fuerza me fue concedérselo. ${ }^{39}$ Así estuve obligado a matarlo y a la muerte le mandé, hacia ella le dirigí. (XLVII, 695)

Cualquier tentativa o acercamiento amoroso lleva necesariamente a la destrucción del otro. Siempre reina la incapacidad de amar plenamente. ${ }^{40}$

38 «Thomas Mann califica una y otra vez la guerra de retorno de lo reprimido, un retorno profundo y violento. Esta expresión forma parte de su "papilla primigenia"» (Kurzke 2004: 264).

${ }^{39}$ En lugar de «mi tuteo», Tollinchi traduce esta frase: «a quien cortejó mi persona (mein Du) con ilimitada confianza, hasta que se la entregué» (1970: 80).

${ }^{40}$ El violinista Rudi Schwedtfeger es otra recreación literaria del también violinista Paul Ehrenberg. Thomas Mann escribe el 16 de julio de 1950 en su diario: «Él [Armin Martens] vive en Tonio Kröger, Willri en La montaña mágica, Paul en Faustus. Todas estas pasiones se han visto hasta cierto punto inmortalizadas» (apud Kurzke 2004: 622). 
Acaso el jovial Félix Krull, el chico de los disfraces, sea la vindicación del Eros encadenado en los sótanos. Thomas Mann se refiere en su diario a esta novela como «der homosexuelle Roman» (25 de noviembre de 1950, 1991: 295). ¿Será acaso porque el creador le otorga a su criatura la posibilidad de vivir libre y plenamente el erotismo ${ }^{41}$

\section{LA VIDA COMO OBRA DE ARTE}

«De mí, de mí...», siempre he hablado de mí parecería gritarnos Thomas Mann en su ensayo Bilse y yo cuando se defiende de las acusaciones de quienes se vieron retratados por su pluma. Thomas Mann, en sus más de cien mil páginas y en los millones de palabras contenidas en ellas, siempre nos hablaba de él. "Todos los personajes», nos dice en el ensayo, «son emanaciones del “yo" que escribe» (1975: 20-21). «Hoy sabemos lo importantes que son las fuerzas del subconsciente, del inconsciente, y cuán decisivo es todo lo que brota de esa esfera esencial que la filosofía llamaba "la voluntad" y que el intelecto solo controla e interpreta a duras penas y a posteriori», nos enseña en On Myself (2016a: 40). Pese a la célebre ironía manniana, un escritor nunca puede distanciarse totalmente de lo que trata en su literatura, máxime cuando recurre a ello una y otra vez. Un gran escritor reescribe sus obsesiones sin curarse nunca de ellas. ${ }^{42}$

Leemos en Muerte en Venecia:

Es, sin duda, positivo que el mundo solo conozca la obra bella y no sus orígenes ni las circunstancias que acompañaron su génesis, pues el conocimiento de las fuentes que inspiraron al artista lo confundiría e intimidaría, anulando así los efectos de la excelsitud. (509)

El gran hombre se equivocaba. Hago mías las palabras de Kurzke: «El conocimiento de las fuentes no desalienta necesariamente, sino que también puede incrementar la emoción y la empatía» (2004: 370). Es en ese trasfondo, transfigurado bellamente a través del arte, donde reside la profunda humanidad de nuestro autor. Y es precisamente la recreación de esa génesis, de esas fuentes vitales a partir de las cuales surge su obra y sobre las cuales medita una y otra vez, el núcleo de su arte. Thomas Mann sabía, al igual que Gustav von

${ }^{41}$ T. J. Reed, al igual que Kurzke (2004: 630-633), explica «the cross-sexual transformation» que se produce en las figuras de la mujer mayor Madame Houpflé ( Thomas Mann) y Félix Krull ( muchacho guapo), acentuada por la «perversión» de ella (la afición por jovencitos y el sadismo), equivalente a la homosexualidad y la fascinación por lo juvenil-masculino para el autor (2006: 52-53). Ella admira las «piernas de Hermes» de Félix Krull (II, 9, p. 235), al igual que Thomas Mann admira las «piernas de Hermes» de un joven argentino jugador de tenis (diario, 6 de agosto de 1950). Solo su hija Erika Mann advirtió «lo archipederasta ("homosexual") de la escena» (Kurzke 2004: 631).

42 «Las motivaciones del escritor son: reelaborar traumas (Sigmund Freud), hacerle un bien al propio narcisismo (Heinz Kohut), compensar una carencia incompensable (Jacques Lacan), saciar un anhelo imposible de satisfacer» (Kurzke 2004: 497). 
Aschenbach, que Eros mora en cada palabra escrita. Hemos advertido la extraordinaria congruencia y organicidad del universo poético de nuestro autor. Por eso es importante escucharlo cuando sugiere en su conferencia de introducción a La montaña mágica para los estudiantes de la Universidad de Princeton (1939) que no se debe interpretar una obra aislada de las demás de su autor, «sin considerar su relación con la totalidad de la obra de una vida y sin tener en cuenta el sistema en el que se encuentra» (2016b: 197). Y más en un autor como él, tan íntimamente autobiográfico. Las claves que propala aquí y allá nos persuaden de su deseo íntimo de dar a conocer al mundo su verdadero yo. Lo dejó dicho en su diario el 25 de agosto de 1950, luego de registrar durante meses su fascinación erótica por un apuesto camarero del Grand Hotel Dolder de Zúrich: «¿Por qué escribo todo esto? ¿Para destruirlo a tiempo antes de mi muerte? ¿O es que deseo que el mundo me conozca?» (apud Kurzke 2004: 627). Estas vivencias tan hondas y personales no solo constituyen la génesis de su obra monumental, sino, más importante aún, su esencia misma. ${ }^{43}$

«iY, sin embargo, sufría!» (Kurzke 2004: 327). Detrás de todas esas máscaras, detrás de su fachada exterior burguesa y de ese edificio vital erigido a su gusto, de esa vida que vista desde fuera parecía construida tan hábilmente, latía íntimamente un dolor profundo, acaso el nostálgico anhelo de cierta complicidad vital. « ¡Ah, he sabido organizarme la vida a mi gusto! ¿Acaso no soy feliz?». La pregunta del payaso seguiría siempre palpitando con fuerza. Desde fuera, solo se veía esa vida ideal, una vida como obra de arte, ordenada y dispuesta de modo admirable, como reconocía el comerciante Schilling en El payaso. «Sí, Thomas Mann tenía éxito, sin duda. Pero también es verdad que lo necesitaba a fin de poder soportar el tormento anímico que le había caído en suerte. [...] Con toda su elocuencia pública, en privado Thomas Mann era extremadamente tímido» (Kurzke 2004: 328). A través del arte fue capaz de transfigurar de modo admirable sus pulsiones más íntimas hasta erigir una gran obra, única en el panorama literario del siglo Xx. Él era consciente de ello. Lo aprendió de Goethe, de quien se consideraba heredero y sucesor, y a quien retrató en Carlota en Weimar como «el espíritu dignificado que esconde lo más íntimo al mundo curioso bajo máscaras rígidas y astutas», según leemos en On Myself (2016a: 96). Sin duda, Thomas Mann fue capaz de transformar los perros salvajes en pájaros y en amables cantoras.

${ }^{43}$ «Como persona, Thomas Mann era hermético y no dejaba que nadie le echara un vistazo a su corazón. Preservaba con disciplina de virtuoso su fachada, sin la cual la vida le habría parecido insoportable. Solo en su obra era libre, solo en ella se comunicaba a los demás, incluidos sus secretos, protegido por la indiscreta discreción del arte. La biografía de su corazón aparece, mágicamente transformada, en sus escritos. A veces, la vivencia auténtica se deja identificar en su literatura sin el menor asomo de duda; otras solo se hace plausible, pero no se deja demostrar. El lector es libre de seguirle o no» (Kurzke 2004: 349). Con todo, también es preciso añadir que «una gran obra es algo más que el mero producto de sus fuentes biográficas» (92). 
Luego de terminar la tetralogía de José y sus hermanos, mientras revisaba viejos apuntes en busca de un nuevo plan de trabajo, Thomas Mann se topó con notas de la época de Tonio Kröger relacionadas con su antiguo amor a Paul Ehrenberg. Y escribió el 17 de marzo de 1943 en su diario:

No se puede experimentar el amor con más fuerza. Pero al final podré decirme a mí mismo que he pagado las consecuencias de todo. La verdadera obra de arte... el truco consistía en hacer la vida capaz del arte. (Mann 1982: 551)

\section{BIBLIOGRAFÍA}

ALDRICH, R. (1993), The Seduction of the Mediterranean: Writing, Art and Homosexual Fantasy, Londres, Routledge.

DIERKS, M. (2005), «Thomas Mann und die Mythologie», en Thomas Mann - Handbuch, Fráncfort, Fischer Taschenbuch, 301-306.

FlauberT, G. (2014), Madame Bovary, Madrid, Alianza. (trad. C. Berges)

GallowAy, D. D. y SABISCH, C. (1982), Calamus: Male Homosexuality in Twentieth-Century Literature: An International Anthology, Nueva York, Morrow.

GARCía PONCE, J. (1967), «El sueño de la nieve», La Palabra y el Hombre, 42, 275-296.

GLANTZ, M. (1976), «Thomas Mann: el problema del artista frente a la vida. De los Buddenbrook al Dr. Faustus», Revista de la Universidad de México, 30(6), 1-12.

KARST, R. (1974), Thomas Mann: historia de una disonancia, Barcelona, Barral. (trad. J. J. del Solar, Thomas Mann oder der deutsche Zwiespalt, Viena-Múnich-Zúrich, Fritz Molden, 1970).

KURZKE, H. (1999), Thomas Mann: das Leben als Kunstwerk. Eine Biographie, Múnich, C. H. Beck.

KURZKE, H. (2004), Thomas Mann: la vida como obra de arte. Una biografía, Barcelona, Galaxia Gutenberg. (trad. R. Sala, Thomas Mann: das Leben als Kunstwerk. Eine Biographie, Múnich, C. H. Beck, 1999)

LAHME, T. (2019), Los Mann: historia de una familia, Barcelona, Navona. (trad. J. Fontcuberta, Die Manns. Geschichte einer Familie, Fráncfort, S. Fischer, 2015)

LOTMAN, I. (1998), La semiosfera II, Valencia, Frónesis Cátedra. (trad. D. Navarro)

MANN, T. (1947), Doktor Faustus. Das Leben des deutschen Tonsetzers Adrian Leverkühn, erzählt von einem Freunde, Estocolmo, Bermann-Fischer.

MANN, T. (1952), Der Zauberberg, Fráncfort, S. Fischer.

MANN, T. (1975), El artista y la sociedad, Madrid, Guadarrama. (trad. M. J. Sobejano)

MANN, T. (1982), Tagebücher, 1940-1943, Fráncfort, S. Fischer.

MANN, T. (1984), Relato de mi vida, Madrid, Alianza. (trad. A. Sánchez Pascual, Lebensabriß, Die neue Rundschau, Berlín-Leipzig, S. Fischer Verlag, 1930)

MANN, T. (1989), Alteza real, Madrid, Aguilar. (trad. J. Moreno de Sosa, Königliche Hoheit, Berlín, S. Fischer, 1909)

MANN, T. (1991), Tagebücher, 1949-1950, Fráncfort, S. Fischer.

MANN, T. (2009), La montaña mágica, Barcelona, Edhasa. (trad. I. García Adánez, Der Zauberberg, Berlín, S. Fischer, 1924) 
MANN, T. (2009), Doktor Faustus, Barcelona, Edhasa. (trad. E. Xammar, Doktor Faustus. Das Leben des deutschen Tonsetzers Adrian Leverkühn, erzählt von einem Freunde, Estocolmo, Bermann-Fischer, 1947)

MANN, T. (2010), Cuentos completos, Barcelona, Edhasa. (trad. R. Sala, J. Fontcuberta, J. J. del Solar et alii, Erzählungen, Fránfcort, S. Fischer, 1964, 1967)

MANN, T. (2012), Confesiones del estafador Félix Krull, Barcelona, Edhasa. (trad. I. García Adánez, Bekenntnisse des Hochstaplers Felix Krull, Fráncfort, S. Fischer, 1954)

MANN, T. (2013), Richard Wagner y la música, Barcelona, Penguin Random House. trad. A. M. de la Fuente, Wagner und unsere Zeit: Aufsätze, Betrachtungen, Briefe, Fráncfort, S. Fischer, 1963)

ManN, T. (2014), Schopenhauer, Nietzsche, Freud, Madrid, Alianza. (trad. A. Sánchez Pascual)

MANN, T. (2016a), Sobre mí mismo, Barcelona, Edhasa. (trad. C. Fortea, Über mich selbst. Autobiographische Schriften, Fráncfort, S. Fischer, 1983)

MANN, T. (2016b), Textos críticos, Barcelona, Navona. (trad. A. Tortajada)

MATAMORO, B. (1981), «Thomas Mann, en sus diarios», Cuadernos Hispanoamericanos, $371,227-265$.

NiETZSCHE, F. (2014), «La gaya ciencia», en Obras completas, Volumen. III, Obras de madurez, I. Sánchez Meca, D. (dir.), Madrid, Tecnos, 703-905. (trad. J. L. Vermal, Die fröhliche Wissenschaft („,la gaya scienza“), Leipzig, Fritzsch, 1887 [1882])

NiETZSCHE, F. (2014), «Humano, demasiado humano», en Obras completas. Volumen III. Obras de madurez I, Sánchez Meca, D. (dir.), Madrid, Tecnos, 59-466. (trad. Marco Parmeggiani, Menschliches, Allzumenschliches. Ein Buch für freie Geister, Leipzig, Fritzsch, 1886 [1878])

NietzSCHE, F. (2016), Así habló Zaratustra, Madrid, Alianza. (trad. A. Sánchez Pascual, Also sprach Zarathustra. Ein Buch für Alle und Keinen, Chemnitz, Schmeitzner, 1883)

NiETZSCHE, F. (2016), La genealogía de la moral, Madrid, Alianza. (trad. A. Sánchez Pascual, Zur Genealogie der Moral. Eine Streitschrift, Leipzig, Neumann, 1887)

NieTZSCHE, F. (1967-), Digital Critical Edition of the Complete Works and Letters, basado en el texto crítico de G. Colli y M. Montinari, ed. Paolo D'Iorio, de Gruyter. Disponible en: <http://www.nietzschesource.org/>.

Platen, A. von (1999), Sonetos venecianos y otros poemas, ed. bilingüe, Valencia, PreTextos. (trad. D. Pujante, Sonette aus Venedig, Erlangen, 1825)

REED, T. J. (2006), "“Der König hat geweint": Loneliness, Eros, and Caritas in Thomas Mann», Oxford German Studies, 45-54.

Robertson, R. (2001), «Classicism and its Pitfalls: Death in Venice», en The Cambridge Companion to Thomas Mann, Robertson, R. (ed.), Cambridge University, 95-106.

SALA, R. (2007), El misterioso caso alemán. Un intento de comprender Alemania a través de sus letras, Barcelona, Alba.

TOlLINCHI, E. (1970), Demonio, arte y conciencia: «Doktor Faustus» de Thomas Mann, Montevideo, Arca.

TOLLINCHI, E. (1973), Las visiones de Thomas Mann, San Juan, Universidad de Puerto Rico. TRÍAS, E. (2017), Thomas Mann, Barcelona, Acantilado.

VARGAS LlOSA, M. (1975), La orgía perpetua. Flaubert y «Madame Bovary», Barcelona, Seix Barral. 
Voltaire (1759), Candide [en línea]. The Project Gutenberg, 2003 [Consulta: 10 de noviembre 2020]. Disponible en: <https://www.gutenberg.org/cache/epub/4650 /pg4650-images.html>.

ZWEIG, S. (2019), Balzac. La novela de una vida, Barcelona, Paidós. (trad. A. Gamboa, Balzac. Der Roman seines Lebens, Estocolmo, Bermann-Fischer, 1946) 